\title{
Çocukluk Sosyolojisinin Tarihsel Gelişimi ve Kuramsal Temelleri
}

\author{
Prof. Dr. Türkan Erdoğan \\ Pamukkale Üniversitesi, Fen-Edebiyat Fakültesi \\ Sosyoloji Bölümü \\ terdogan@pau.edu.tr
}

\author{
Bilge Vakuf \\ Pamukkale Üniversitesi, Sosyal Bilimler Enstitüsü \\ Doktora Öğrencisi \\ bilgevakf@hotmail.com
}

Öz

Bu çalışma, "geleneksel" çocukluk sosyolojisinden "yeni" çocukluk sosyolojisine doğru evrilen çocukluk sosyolojisinin gelişme çizgisini, çocuğa yönelik yeni eğilimlerini ve kuramsal temellerinin nasıl biçimlendiğini tahlil etmeyi amaçlamaktadır. Literatür taramasına ve değerlendirmesine dayalı olarak gerçekleştirilen çalışma, amacı doğrultusunda kuramsal bir nitelik arz etmektedir. Çocuk ve çocukluk dönemine ilişkin çalışmalar yapan çocukluk sosyolojisi, sosyoloji disiplini içerisinde tarihsel, kültürel, politik vb. koşullar sebebiyle daha geç tarihsel bir dönemde gelişmiştir. Geleneksel çocukluk sosyolojisi "sosyalizasyon" paradigması üzerinden gelişirken, yeni çocukluk sosyolojisi, "toplumsal aktör/toplumsal inşa olarak çocuk" anlayışı çerçevesinde gelişmiştir. Feminist hareketler, çocuk haklarının gelişimi, çocuğa yönelik yeni sosyolojik yaklaşımlar, çocukluk sosyolojisi anlayışını yeniden biçimlendiren gelişmeler olmuştur.1990'lı yıllardan itibaren çocuklara yönelik sosyolojik çalı̧̧maların artması, çocuk araştırma merkezlerinin kurulması ve çocukluk konusunun sosyoloji bölüm programlarında yer alması, yeni çocukluk sosyolojisi çalı̧̧malarının gelişimini hızlandırmıştır. Sonuç olarak, söz konusu toplumsal gelişmelerin etkisinin yanı sıra çocukluk sosyolojisi alanındaki mevcut literatüre ilişkin değerlendirmeler, bu disiplinin olgunlaşma sürecini halen yaşamakta olduğunu göstermektedir. Çocukluk sosyolojisinin gerek konuları bakımından çok boyutlu ve derinlikli bir yapı arz etmesi, gerekse beslendiği inceleme alanının disiplinlerarası bir içerikte olması onun gelişim mecrasını belirlemede ve yönlendirmede etkili olmaktadır.

Anahtar Kelimeler: Çocukluk sosyolojisi, sosyalizasyon, yorumlayıcı yaklaşım, toplumsal aktör, çocuk.

\section{Historical Development and Theoretical Foundations of Childhood Sociology}

\section{Abstract}

This study aims to analyze the development of the sociology of childhood, which transforms from "traditional" to "new" sociology of childhood, through examining new trends for children and how its theoretical bases are shaped. The study, which is based on the literature review and evaluation, has a theoretical quality in line with its purpose. Studying on children and childhood, the sociology of childhood made progress in a relatively late period within the discipline of sociology due to historical, cultural, political, 
etc. conditions. While the traditional sociology of childhood developed through the "socialization" paradigm, the new sociology of childhood developed within the framework of the "social actor / child as social construct" perspective. Feminist movements, development of children's rights, new sociological approaches on children have been the developments that reshaped the concept of sociology of childhood. Increasing sociological studies after the 1990s, the establishment of children research centers and the inclusion of childhood in curriculum of sociology departments have accelerated the development of the new sociology of childhood studies. In conclusion, together with the impacts of these social developments, the evaluations regarding the current literature in the field of the sociology of childhood indicate that this discipline is still in its maturation process. The fact that the sociology of childhood has a multidimensional and deep structure in terms of its subjects, and the area of study it feeds in has an interdisciplinary content is effective in determining and directing its course of development.

Keywords: Childhood sociology, socialization, interpretive approach, social actor, child. 


\section{GİRIŞ}

Sosyal bilimler alanında çocuk konusunda yapılan araştırmalara genel olarak bakıldığında bu çalışmaların, "çocukluk çalışmaları" ya da "çocukluk incelemeleri" başlığı altında ele alındığı görülmektedir. Çocukluk çalışmalarının ne zaman ve nasıl başladığına yönelik kesin bir bilgi bulunmamakla birlikte, çocuğun toplumsal konumunu, kültürünü ve tarihselliğini ele alan bir çalışma olması sebebiyle Philippe Ariés'in Çocukluğun Yüzyılları (Centuries of Childhood, 1962) adlı eseri sosyal bilimler alanında temel eser olarak kabul görmektedir.

Çocukluk sosyolojisi ${ }^{1}$, kent sosyolojisi, suç sosyolojisi, bilgi sosyolojisi gibi sosyolojinin birçok alt dalına göre geç gelişen bir alandır. Akın'a $(2015$, s. 46) göre çocukluk sosyolojisi genel sosyolojinin bir alt dalı disiplini olarak ancak 1970'lerden itibaren gelişmeye başlamıştır. Bu yıllarda gerçekleştirilen çalışmaların yöneldiği alanların başında çocuktoplum ilişkisi ve sosyalizasyon gelmektedir. Çocuklar konusunda araştırmalar yapan bilim insanı sayısının yaklaşık 20-30 yıl öncesine kadar az sayıda olduğuna dikkat çeken James de (2001, s.27) 1980'li ylllardan itibaren çocuklara yönelik sosyolojik ve antropolojik ilginin giderek arttığını, özelllikle İngiltere ve ABD başta olmak üzere Avustralya, İskandinavya ve Avrupa ülkelerinde çocuk kültürü araştırmalarının ve çocukları inceleyen merkez sayısının gittikçe çoğaldığını söylemektedir.

Aynı zamanda bir ön hazırlık evresi olarak da kabul edebileceğimiz çocuğa yönelik sosyolojik çalışmaların tarihsel arka planı, daha erken bir döneme dayanmaktadır. Çocukluk sosyolojisinin tarihsel ve kuramsal temellerinin dünya üzerindeki oluşum ve gelişim süreci farklı şekillerde seyretmiş ve 1920'li yıllarda Amerika'da Chicago Üniversitesi Sosyoloji Bölümünün çocuğa yönelik gerçekleştirdiği sosyolojik araştırmalar çocukluk sosyolojisi çalışmalarına öncülük etmiştir. "Çocukluk sosyolojisi" başlı̆̆ı altında çocukların incelenmesi, çocuğa yönelik araştırma ve yayınların artması, üniversitelerde çocukluk sosyolojisi derslerinin açılması; ABD, İngiltere ve diğer Avrupa ülkelerinde feminist hareketlerin ortaya çıkması, çocuk haklarının gelişimi, çocuklara yönelik yeni sosyolojik yaklaşımların (yapısal çocukluk yaklaşımı, yorumlayıcı yaklaşım vb.) gelişimi gibi toplumsal süreçler, çocukluk sosyolojisinin kuramsal gelişimini etkilemiş, böylelikle yeni çocukluk sosyolojisinin oluşmasına da zemin hazırlamıştır.

Çocukluk sosyolojisinin gelişim süreci ve kuramsal temelleri ele alındığında iki farklı çocukluk sosyolojisi yaklaşımının var olduğu görülmektedir. İlki, 1980 öncesi dönemde çocukluk sosyolojisinin ayn zamanda temelini de oluşturan geleneksel (klasik) çocukluk sosyolojisi anlayışıdır. William A. Corsaro'nun altını çizdiği gibi geleneksel çocukluk sosyolojisi, çocuğu daha çok sosyalizasyon süreciyle ilintili ve pasif konumda (Corsaro, 2005, s.8) bir sosyal varlık olarak ele almıştır. Tek yönlü nedensellik ilkesinin gözetildiği bu çalışmalarda çocuk, genellikle aile ve okul/eğitim bağlamında toplumun norm ve değerleri yöneliminde belirlenen ve biçimlendirilen edilgen bir varlık olarak benimsenmiştir. İkincisi, 1980'li yıllardan itibaren gelişme kaydeden "yeni çocukluk sosyolojisi" çalışmalarıdır. Geleneksel çocukluk sosyolojisine karşı eleştirel bir duruş sergileyen bu yeni yaklaşım, çocuk bireyin salt sosyalizasyon süreciyle sinırlandırılarak edilgen bir konumda ele

1Tarihsel gelişimine bakıldığında sosyolojinin bir alt dalı olarak çocukluk sosyolojisi literatürde, çocuk sosyolojisi ya da çocukluk sosyolojisi başlıkları altında ele alınmaktadır. Bu çalışmada söz konusu alt disiplin için çocukluk sosyolojisi tanımlaması esas alınmıştır.

SEFAD, 2020; (44): 461-486 
alınmasına karşı çıkmış, yerel/kültürel açıdan farklı çocukluk bilincini aşılayan çalışmalara da yol gösterici olmuştur.

Çocukluk sosyolojisinin popüler hale gelmesini sağlayan yeni çocukluk sosyolojisi, güncel literatürde aynı zamanda "çağdaş çocukluk sosyolojisi" olarak da adlandırılmaktadır. Çocuk bireyin toplumda aktif bir özne olduğunu vurgulayan yeni çocukluk sosyolojisine göre çocukluk sosyal olarak yapılandırılmaktadır. Çocukların toplumsal bir aktör olduğuna dikkat çeken bu yaklaşım, çocukların sosyolojik açıdan incelenmeye değer varlıklar olduğunun altını çizmiştir (James, 2001, s.28). Böylelikle yeni çocukluk sosyolojisi, çocuk ve çocukluğa ilişkin bilimsel anlayışın kuramsal temellerini belirlemenin yanı sıra onun metodolojik yol haritasını da yeniden çizmiştir. 1980'li yıllardan sonra gerçekleştirilen çocukluk araştırmalarında nitel araştırma yöntemlerinin revaçta olmasını bu gelişmelere bağlayabiliriz.

Çocukluk sosyolojisinin gelişim çizgisini ve eğilimini ortaya koymak ve kuramsal temellerinin nasıl biçimlendiğini tahlil etmek amacıyla bu makalede, çocukluk sosyolojisinin dünyadaki tarihsel gelişim süreci ele alınmaktadır. Aynı zamanda 1980'li yıllardan itibaren yeniden biçimlenen çocukluk sosyolojisinin belirli ülkelerdeki gelişim çizgisi ortaya konulmaktadır. Bu amaçla çalışmanın ilk bölümünde çocuk ve çocukluk kavramları sosyolojik açıdan ele alınmıştır. İkinci bölümde 1980 öncesi dönemde çocukluk sosyolojisinin gelişmesine ön ayak olan kuramsal temeller ve belirli öncü ülkelerdeki çocukluk sosyolojisinin gelişim çizgisi tartışılmıştır. Çalışmanın son bölümünde ise çocukluk sosyolojisini yeniden biçimlendiren, çocuğa yönelik yaklaşımın farklı boyutuna kapı aralayan yeni çocukluk sosyolojisinin ana hatları üzerinde durulmuş, yeni çocukluk sosyolojisinin geliştiği ülkelerin çocukluk sosyolojisi alanına ilişkin katkılarına değinilmiştir.

\section{ÇOCUK VE ÇOCUKLUK KAVRAMLARI}

Toplumların çocuk ve çocukluk sürecini nasıl tanımladıkları, o toplumların aynı zamanda sosyo-kültürel yapılarının özellikleri ile ilintilidir. "İnsanın çocukluğu diye bir şey var mıdır? İnsani olgu olarak çocukluk nasıl mümkündür? Mümkünse, yeri neresidir?" (Agamben, 2010, s.57) ve "Çocuk kimdir?" şeklinde çocuk ve çocukluğun anlamına dair sorular, çocuk kavramı ve çocukluk sürecinin tanımlanmasını gerekli kılmaktadır.

Dünya geneline bakıldığında farklı toplumlarda çocuk kavramının fiziksel, biyolojik özelliklerden ya da yaş gibi değişkenlerden hareketle tanımlandığı görülmektedir. Sözgelimi, yaş değişkenine göre çocuk denildiğinde 0-18 yaş aralığında bulunan bireyler (Pembecioğlu, 1997, s.253) kastedilmektedir. Fiziksel ve biyolojik özellikleri ele alan tanımlara göre ise çocuk, gelişen-gelişmekte olan bireydir. Çocuğa ilişkin biyolojik temelli tanımlamaların çocuğu yeni ulus devlet fikrine uygun dar bir tanımlama içine hapsettiğine dikkat çeken Eğribel, (2019, s.46) eleştirel bir dille bu tür bir tanımlama biçiminin çocuk sorunları ve bu sorunların çözümünde ırkçılığa yol açan görüşleri savunmaya açık hale getirebileceğine işaret etmektedir.

Birçok kültürde çocuk, geleceğin toplumunun hazırlayıcısı olarak görülmektedir. Çocuk bir bakıma gelecekteki toplumun aynı zamanda kendisi konumundadır. Çocuk, toplumsal yaşamın merkezinde yer alan, dünyanın ve toplumların yükselen biricik değeridir (Şirin, 2017, s.9). Margaret Mead çocukların toplumsal yaşamın içinde aktif rollere sahip olduğunu ve kendilerine özgü yaşam dünyalarına sahip olduklarını belirtmektedir (Tezcan 2017, s.1). Stearns'e (2018, s.39) göre de çocuk, etrafını saran bir toplumu yansıtır ve toplum 
içinde sosyalleşerek toplumun oluşmasına katkıda bulunur. Bu nedenle çocuk toplumun, kültürün, devletin ve ailenin ayrılmaz bir parçasıdır. Her toplum, her kültür ya da her aile kendi çocukluk algısını, çocukluk kültürünü ve çocuğun içine doğduğu habitusu üretmektedir. Çocukluk döneminin sanayileşmiş toplumlarda gelişmekte olan toplumlara nazaran daha uzun süre yaşandığına dikkat çeken Çöpoğlu'na (2018, s.361) göre bunun temel nedeni, çocukluk anlayışının sosyo-kültürel açıdan, zaman açısından ve farklı toplumlarda çocukluğa yüklenen değişik anlamlar açısından değişiklik göstermesidir. Bununla ilgili benzer bir tespitte bulunan Karaduman ve Tökgöz (2017, s.378) Avrupa'da modernizm ideolojisinin kendine özgü bir çocukluk anlayışı ürettiğini ileri sürerler. Onlara göre "temelinde adalet, hak, özgürlük ve eşitlikçi düşünceye dayanan modernizm ideolojisinin, çocuğu da bu yönelimin bir uğ rağı olarak" görmüştür.

İnsanın zamansal açıdan geçirdiği bir gelişim süreci olarak çocukluk kavramı, "insan hayatının gerçeği" (Holt, 2000, s.7) ya da "yaşamın açı ve seçik aşaması" (Giddens, 2008, s.215) olarak karşımıza çıkar. Çocukluğu başlı başına bir dönem olarak değerlendiren Çöpoğlu'na (2018, s.361) göre çocukluk dönemi "bir sonraki süreç olan yetişkinlik yaşamına hazırlanma aşamasında bakılma, korunma ve eğitilme süreçlerinin yaşandığı evredir."

Çocukluk kavramı ve çocukluk anlayışı birbirinden farklı anlamları ifade etmektedir. Çocukluk kavramı her toplumda mevcut iken, çocukluk anlayışı ise farklı toplumlar ve farklı tarihsel dönemlere göre değişebilmektedir (Onur, 2005, s. 27-28). Dolayısıyla farklı toplumlarda, farklı tarihsel dönemlerde ya da bir toplum içinde çocukluğa yüklenen anlam, verilen değer itibariyle çocukluk "toplumsal bir kurgu" (Postman, 1995, s.7) olarak da anlaşılmaktadır.

Çocukluk anlayışı bir toplumun tarihsel ve kültürel süreci içerisinde gelişir (Onur, 1994, s.3). Çocukluk anlayışı modern anlamıla toplumsal norm ve değerlere göre belirlenen, bölgeye, yaşanılan toplumsal çevreye, dinsel ya da kişisel görüşlere, farklı toplumsal yapılara ve farklı tarihsel dönemlere göre değişebilen ve toplumsal-kültürel yapı içerisinde inşa edilen bir algıya sahiptir (Tan, 1989, s.7; Kaya, 2012, s.109). Örneğin ortaçağda çocuğa verilen ilgi ve değer az iken, değişen sosyo-kültürel ve ekonomik koşulların etkisiyle modern dönemde çocuğa daha yüksek değer atfedilmiş, çocukluk süreci yetişkinden ayrı ve özel bir evre olarak kabul edilmiştir (Doğan, 2000, s.64-80; Ariés, 1962, s.128).

Genel olarak ifade edilirse sosyo-kültürel bir kavram olarak yapılandırılan çocukluk sürecinde çocuklar, yetişkinlerle olan etkileşimleri ve gündelik yaşamlarındaki çeşitlilik sebebiyle çocukluğu birbirinden farklı deneyimlemektedirler (James, 2001, s.29). Nitekim ekonomik, teknolojik, çevresel koşullar, çocukların toplumsal yaşamını belirlemekte, değiştirmekte (Güçlü, 2016, s.3) ve çocukların gündelik hayatlarını farklı şekilde deneyimlemelerine yol açmaktadır. Dolayısıyla çocuğun değişen koşullara bağlı olarak hukuksal durumu, ekonomik yönü, toplumsal rolleri, statüsü ve eylemliliği de değişebilmektedir. Günümüzde söz konusu değişmelere hem tanıklık eden hem de bu değişimlerin yönü ve içeriğini kapsamlı ve derinlikli bir şekilde ele alan sosyoloji bilimi ise çocukların değişen koşullara bağlı olarak yaşamlarını nasıl deneyimledikleri, değişen koşullardan nasıl etkilendikleri ve topluma nasıl katıldıklarını irdeleyerek çocukluğa ilişkin bilimsel anlayışa katkı sağlamaktadır. 


\section{0 ÖNCESİ DÖNEM: GELENEKSEL (KLASİK) ÇOCUKLUK SOSYOLOJİSINIIN TARİHSEL ARKA PLANI}

Sosyolojinin içine doğduğu sosyo-politik şartlar ve mevcut bilim anlayışı onun disipliner karakteri, metodolojik anlayışı ve kuramsal gelişiminde belirleyici bir rol oynamıştır. Nitekim 19. yüzyılın hâkim epistemolojik (pozitivizm) ve ontolojik (holistik) yaklaşımları ile Fransız Devrimi ve Sanayi Devrimi gibi iki önemli tarihsel olayın (Gürdal, 2013, s.4) etkisiyle sosyoloji bilimi, öncelikle "modern toplumu" açılamayı kendine görev edinmiştir. Çocukların toplumda ve kuramlarda ikincil konumda yer alması, çocukların içinde bulunduğu toplumsal yaşamlarından ziyade, gelecekteki yetişkin konumlarına (Onur, 2007, s.39) ve çocukların sosyalizasyon sürecine odaklanılması (Özyurt, 2017, s.126), çocukluk sosyolojisinin geç tarihte oluşmasına yol açmıştır. Bu nedenle çocukluk sosyolojisi alanının gelişim ve kuramsallaşma dönemlerini 1980 öncesi geleneksel (klasik) çocukluk sosyolojisi ve 1980 sonrası "yeni (çağdaş) çocukluk sosyolojisi" olarak ayırabiliriz.

20. yüzyılda bir bilim dalı olarak ilk önce çocukluk tarihinin, sonraki süreçte ise çocukluk sosyolojisinin bir alt disiplin dalı olarak (Onur, 2019, s.323) öne çıtığı söylenebilir. Çocukluk tarihi alanında yapılan çalışmaların başında Philippe Ariés'in Çocukluğun Yüzyılları (Centuries of Childhood, 1962) adlı eseri gelmektedir. Bu eser, çocukluğun toplumsal konumunu, tarihini ve kültürünü araştırması sebebiyle sosyal bilimlerde çocukluk çalışmalarına katkı sağlayan çalışmaların öncüsü sayılmaktadır. Ariés çalışmasında çocukların aile ve okul hayatını, gündelik yaşamlarını inceleyerek toplumsal çocukluğun keşfini ortaya koymaya çalışmıştır. Ariés'in söz konusu eseri, sosyal aktör olarak çocuğun keşfedilmesi yönünde diğer çalışmalara fikir sağlamış ve "psikoloji, psikiyatri, eğitim, sosyal hizmet, sosyoloji, antropoloji, tarih ve hukuk gibi farkl disiplinler tarafindan çocuğun kavramsallaştırılması ve çalışılmasına" dönük bilimsel ilgi ve eğilimi artırmıştır (Gürsoy, 2010, s.141). Dolayısıyla bu çalışma sosyal bilimlere katkı sağlamakla birlikte çocuğun toplumdaki yeri, değeri, yetişkinlerden farkı gibi konularda çocuğun toplumsal açıdan araştırılmasına ilişkin farkındalık oluşturmasıyla özellikle çocukluk çalışmalarının ve çocukluk sosyolojisinin şekillenmesinde ön ayak olmuştur.

Çocukluk çalışmalarında uzun bir dönem psikoloji biliminin baskın olması nedeniyle geleneksel çocukluk sosyolojisi çalışmalarında psikolojik açıklamalar hâkim olmuştur (Prout ve James, 2005, s.9). Psikoloji bilimi, 19. yüzyılın sonuna doğru sosyoloji bilimi ile işbölümü yapmış ve bu işbölümü neticesinde önce çocuk ve çocukluk konusu sonrasında ise aile konusu temel alınarak çalışılmıştır. Bu durum sosyolojinin çocukları kısmen aile dışına itmesine ve çocuğun araştırılmasını hususunu psikolojik çalışmalara devretmesine yol açmıştır. Bu nedenden ötürü çocukluk araştırmaları aile çalışmaları çerçevesinde sınırlı kalmıştır (Turmel, 2008, s.18) ve ilk dönem çocukluk sosyolojisi, genellikle ailesi ve çevresine bağımlı, kontrol edilen, eğitim ve okul gibi sosyal çevreye adapte edilen çocuğun sosyalizasyonu konusuna ağırlık vermiştir.

Özellikle psikolojinin bir alt dalı olan gelişim psikolojisinin, çocuğun toplum içindeki yeri ve çocukluğun gelişim süreci konularında çocukluk sosyolojisinin oluşumuna katkı sağladığını belirtebiliriz. Gelişim psikolojisi, çocuğun doğallığı kavramını ve kültürü ön plana koyarak çocukların gelişim sürecindeki durumuna odaklanmıştır (Onur, 2007, s.45; Prout ve James, 2005, s.9). Gelişim psikolojisinde Jean Piaget'in öğrenme teorisi, çocuk gelişimi ve çocuk bakımı üzerine ortaya koyduğu çalışmalar, Lev Vygotsky'nin çocuğun gelişimine yönelik öne sürdüğü teori, eğitim alanındaki gelişmeleri mümkün kılmıştır 
(Jenks, 2002, s.22; Onur, 2007, s.53-54). Ne var ki psikoloji alanındaki araştırmalarda çocuğun başlı başına bir birey olduğu ve sosyalizasyon sürecine aktif olarak katıldığı anlayışının göz ardı edilmesi çocukluk sosyolojisi alanının gelişimini kısıtlamıştır. Bu kısıtlanmanın etkisiyle ilk dönem çocukluk sosyolojisi çalışmalarını "evrensellik, doğallık ve rasyonellik" kavramları şekillendirmiştir denilebilir. Bu kavramlar çocukluğa yönelik sosyolojik yaklaşımları ve çocukluğun sosyo-politik durumlarını etkilemiştir. Geleneksel dönemde pozitivizmin baskın olması sebebiyle daha çok çocukların topluma katılımına yönelik bilimsel açıklamalara yer verilmiş, yapısal-işlevselci yaklaşımın etkisiyle çocuk bireye sınırlı roller biçilmiştir (Prout ve James, 2005, s. 10,12).

Yeni çocukluk sosyolojisinin gelişimiyle çocuğun birer sosyal aktör olarak sosyal çevresine etkin katılımı ve toplumdaki inşacı rolü gündeme getirilmiştir. Psikolojik deneyler, sosyometrik haritalar, etnografik tanımlamalar, boylamsal araştırmalar, bilgi teknolojisinde yaşanan gelişmeler çocukluk sosyolojisinde uygulanmaya başlanmış ve böylelikle çocukluğa yönelik düşünce biçimi yeniden yapılandırılmıştır (Prout ve James, 2005, s.9). Söz konusu gelişmelere paralel olarak çocukluk sosyolojisinde belirleyici olan psikolojik açıklamalar da zamanla etkisini yitirmeye başlamıştır. Dünya geneline bakıldığında 1980 öncesinde psikolojinin gölgesinde ilerleyen geleneksel çocukluk sosyolojisinin farklı toplumlarda, farklı tarih ve koşullarda gelişme kaydettiği görülmektedir. Sözgelimi, ABD’nde sosyoloji araştırmalarında çocuklara yönelik çalışmaların gerçekleştirilmesi 1920'li yıllara dayanmaktadır. Çocukluk sosyolojisi alanının gelişmesine Chicago Üniversitesi Sosyoloji Bölümünün çocukluk çalışmaları katkı sağlamıştır (Johnson, 2001, s.53-54). Fakat bu yıllarda ABD çocukluk çalışmalarında daha çok gelişim psikolojisi hâkim olduğu için ilk dönem çocukluk sosyolojisinin başlı başına bağımsız bir alt bilim dalı olarak gelişmediği görülebilir. Buna rağmen çocukluğu "toplumsal olgu" olarak ele alan çalışmalara da rastlanmaktadır. Mayall (2018, s.9), bu konuda James W. Trent'in 1987 tarihli “A Decade of Delaining Involvement: American Sociology in the Field of Child Development, the 1920s'" adl makalesini örnek vermektedir. Çocukluğu "toplumsal bir olgu" olarak ele alan J. W. Trent, çalışmasında çocuklara yönelik bu bakış açısının arka planının 1920-1930'lu yıllarda yapılan çalışmalara dayandığından söz etmiştir.

1950'li yıllara gelindiğinde ise ABD'de çocuk konusunun sosyalizasyon paradigması açısından daha çok aile ve eğitim ekseninde ele alındığı görülür. Bu yıllarda "çocuk suçluluğu" üzerine odaklanan temel çalışmaların yanı sıra çocuk ve toplum ilişkisini inceleyen, çocuğun sosyal önemine vurgu yapan ilk çalışmalar da literatürde yer bulmaya başlamıştır. Erik Erikson Çocukluk ve Toplum (Childhood and Society, 1950) adlı eserinde çocukluğu fiziksel, sosyal ve zihinsel bir etkileşim içinde ele almış ve sosyalizasyon kuramını ortaya koyarak çocukluk çalışmalarına katkı sağlamıştır (Johnson, 2001, s.60-61). Kısaca belirtmek gerekirse 1960'lı yıllarda çocuğa ilişkin sosyolojik yaklaşımlar sosyalizasyon paradigması anlayışıyla şekillenmiş, deneysel (ampirik) incelemeler ve kuramsal çalışmalar bu bağlamda üretilmiştir.

ABD'deki gelişim sürecine benzer şekilde İngiltere'deki çocukluk sosyolojisi de sosyalizasyon paradigması üzerinden şekillenmiştir (Ellis, 2010, s.187). İngiltere'de çocukluk sosyolojisinin kuramsallaşma süreci, ancak Alan Prout ve Allison James gibi bilim insanlarının aktif sosyalizasyon yaklaşımını benimsemeleri sayesinde mümkün olabilmiştir. Almanya'da ilk dönem çocukluk sosyolojisi yine eğitim ve sosyalizasyon paradigması etrafında gelişmiştir (Zeiher, 2010, s.292). Fransa'da ise ilk dönem çocukluk sosyolojisi, 
eğitim sosyolojisi alanından da yararlanarak sosyalizasyon paradigmasını eleştiren anlayış içerisinde ancak 1990'lı yıllarda (Sirota, 2010, s.250) şekillenebilmiştir. İtalya'ya bakıldığında 1970'li ve 1980'li yıllarda daha çok ergenlik çalışmalarının yoğunlaşması ve psikolojik çalışmaların hâkimiyeti sebebiyle bu ülkede çocukluk sosyolojisinin, yukarıda zikrettiğimiz diğer ülkelerdeki gelişmelere paralel şekilde geleneksel sosyalizasyon paradigması perspektifinde (Baraldi, 2010, s.272-273) ilerlediği görülür.

\section{SONRASI DÖNEM: ÇOCUKLUK SOSYOLOJISINININ YENIDEN BİÇIMLENMESİ}

Geleneksel çocukluk sosyolojisi, yukarıda ifade edildiği gibi 1980 öncesi dönemde daha çok çocukların "sosyalizasyonu" sorunsalı üzerinde durarak gelişme kaydetmiştir. 1980 'li yıllardan itibaren ise çocukluk sosyolojisi, aşağıda detaylı bir şekilde aktarılacağı üzere konuları ele alış tarzı, bilimsel yaklaşımı ve çocuğa yüklediği anlam itibariyle geleneksel çocuk sosyolojisinden ayrılarak "yeni çocukluk sosyoloji" başlığı altında farklı bir seyir izlemiştir.

Yeni çocukluk sosyolojisinin kuramsal temelleri, İngiltere'de özellikle 1990'l1 yıllarda Alan Prout ve Allison James'in çocuklara yönelik pasif sosyalizasyon ağırlıklı yaklaşımı eleştirmeleri ve farklı bir çocukluk anlayışı öne sürmeleri ile atılmıştır. A. Prout ve A. James, Çocukluğun İnşası ve Yeniden İnşası (Constructing and Reconstructing Childhood, 2005) adlı eserlerinde yeni çocukluk sosyolojisi paradigmasını öne sürmüşler, çocuğun tıpkı yetişkin birey gibi "toplumsal bir yapı ve toplumsal bir aktör" olarak ele alınması gerekliliğini vurgulayarak yeni çocukluk sosyolojisinin kuramsallaşmasının yolunu açmışlardır. Yeni çocukluk sosyolojisine yönelik bu öncü eser, çocukluğun toplumsal olarak nasıl inşa edildiğini keşfetmeyi amaçlamış ve çocukluğun konumu ile ilgili çağdaş endişeleri dile getirmiştir (Prout ve James, 2005, s.1). Yeni çocukluk sosyolojisinin kuramsal temellerine katkı sağlayan iki önemli eseri daha burada zikredebiliriz. Bu eserden ilki, Allison James ve Adrian L. James'a ait Çocukluğu Yeniden İnşa Etmek: Teori, Politika ve Sosyal Çalışmalar (Constructing Childhood: Theory, Policy and Social Practice 2004) adlı eserdir. Ad1 geçen yazarlar, eserlerinde hukuk ve politikanın çocukluğun inşasındaki etkisini ve eğitim, sağlık, suç ve aile gibi değişkenlerin çocuklukla olan ilişkisinin sosyolojik boyutunu irdelemişlerdir. Bir diğer öncü eser ise çocuk ve toplum arasındaki ilişkiye odaklanan William A. Corsaro'a ait Çocukluk Sosyolojisi (The Sociology of Childhood, 2005) adlı eserdir. Aşağıda detaylı bahsedileceği üzere yorumlayıcı yaklaşımı izleyen Corsaro, (2005) geleneksel, inşacı ve yorumlayıcı toplumsal çocukluk kuramlarını ele aldığı çalışmasında çocukları toplumsal aktör olarak ele almış, yerel/kültürel/bölgesel açıdan farklı çocukluk biçimlerine değinmiştir. Toplumsal değişim sürecinin ve toplumsal sorunların çocuklar üzerindeki etkisini de sorgulayan Corsaro, çocukların güncel konular (savaş, boşanma, yoksulluk, şiddet, sivil toplum vb.) bağlamında da ele alınması gerektiğini vurgulamıştır. Corsaro, bu eseri örneğinde aynı zamanda günümüzdeki çocukluk çalışmalarında var olan bakış açısı eksikliğine de dikkat çekmiş olmaktadır.

Yeni çocukluk sosyolojisi farklı toplum, kültür ve bölgelerde çocuk olmanın anlamını sorgulamak, çocukların hayatlarını nasıl biçimlendirdiğini irdelemek, çocukların toplumsal etkinlik kalıplarını nasıl oluşturduklarını öğrenmek ve diğer bireylerle ilişki biçimlerini anlamak anlayışı ile hareket etmiştir (Hammersley, 2019, s.64). Bu nedenle yeni çocukluk sosyolojisi, "çocukların 'edim'ini (seçim yapma ve bu seçimleri yaşam içinde uygulama kapasitesi) vurgulayarak yetişkinlerle ve kendi aralarmdaki etkileşimlerinin çocukluğun ve toplumun doğasın 
değiştiren, meydan okuyan ve yenileyen muhtelif yönlerini incelemeyi" (Leonard, 2019, s.107) amaç edinmiştir.

Yeni çocukluk sosyolojisinin çocuklara yönelik yaklaşımında çocuklar, kendi toplumsal dünyalarını anlamlandırabilen ve etkileyebilen aktif sosyal aktörler olarak tanımlanmaktadırlar. Bu nedenden ötürü söz konusu yaklaşımda çocuklar, yetişkinler tarafından kültürlenmiş ya da sosyalleştirilmiş varlıklar olarak ele alınmak yerine "yorumsal yeniden üretim" kavramı çerçevesinde irdelenmişlerdir. (Matthews, 2007, s.324). Yorumsal yeniden üretim kavramını sosyolojideki yorumlayıcı yaklaşım dâhilinde başlı başına bir model olarak değerlendiren Corsaro'ya $(2005$, s.8,18) göre yorumsal yeniden üretim, çocuğun sosyalizasyona katılımında onun aktif özne olma yönüne vurgu yapar. Bu anlayışta sosyalizasyon, yapıdan faile (toplumdan bireye) doğru tek yönlü bir belirlenmişlik ya da etkilenme çizgisinde gerçekleşmez, tam aksine yapı-fail etkileşimine dayanır ve çocuk birey, bu süreçte toplumsal ilişkilerin ve değerlerin inşasında bir özne/eyleyen olarak rol alır. Çocukların topluma katılımlarında yenilikçi ve yaratıcı yönlerini araştıran yorumlayıcı yaklaşım aynı zamanda çocuğun eylemliliğini, toplumu ve kültürü içselleştirmesini, kültüre ve değişime nasıl katkı sağladığını ortaya çıkarır. Bu bağlamda Corsaro, çocukların toplumsal yapıya aktif olarak katılımlarının önünü açan, çocukların eylemliliğini vurgulayan ve yeni çocukluk sosyolojisine imkân sağlayan yorumsal yeniden üretim modelini, çocukluk sosyolojisinde yararlı bir model olarak değerlendirmiştir. Yorumsal yeniden üretim modeli, çocukluk sosyolojisinde çocuğun bir taraftan aktif fail olarak ele alınması gerektiğini, diğer taraftan da günlük yaşamda farklı çocukluk biçimlerinin var olduğu gerçeğinin bilimsel açıdan incelenmesi hususunu belirtmiştir. Bu açıdan bakıldığında yeni çocukluk sosyolojisinde yorumlayıcı yaklaşımı benimseyen bilim insanlarının, yorumsal üretim kavramını sosyalizasyon kavramına alternatif olarak kullandıklarını belirtebiliriz.

Genel itibariyle yeni çocukluk sosyolojisi, çocukların sosyolojik açıdan incelenmesine yönelik öne sürdüğü toplumsal yapı, aktör çocuk, sınıf, etnisite ve toplumsal cinsiyet gibi değişkenlerden hareket etmekte ve çocukluk sosyolojisinin kuramsal temellerini bu değişkenler bağlamında oluşturmaktadır. Bu hususla ilgili olarak Prout ve James, (2005, s.8) ayrıca çocukluk sosyolojisinin bir paradigma olarak ele alınması gerektiği hususuna dikkat çekerek söz konusu paradigmanın temel özelliklerinden şu şekilde söz etmektedirler: Yeni çocukluk sosyolojisi paradigması, çocukluğu toplumsal bir yapı olarak ele almaktadır. Çocukluk, biyolojik ve evrensel özellikten farklı olarak toplumun yapısal ve kültürel öğesi olarak görülmelidir. Çocukluk, sosyal analizin bir değişkenidir ve sınıf, toplumsal cinsiyet ya da etnisite gibi diğer değişkenlerle birlikte ele alınmalıdır. Kültürlerarası karşılaştırmalı analizler tek ve evrensel çocukluk anlayışı yerine çocukluk dönemlerinin çeşitliliğini ortaya koymaktadır. Çocukların sosyal ilişkileri ve kültürleri, yetişkinlerin bakış açıları ve ilgilerinden bağımsız, kendi doğruları içinde çalışılmayı hak etmektedir. Bu bağlamda çocuklar gerek kendi sosyal yaşamlarında gerekse genel toplumsal yaşamın içinde ve işleyişinde birer etkin aktörler olarak görülmelidirler. Etnografya, çocukluğun çalışılmasında özellikle işlevsel bir yöntemdir ve çocuklara, sosyolojik verinin üretilmesinde doğrudan bir ses ve katılım olanağı sağlar. Yeni çocukluk sosyolojisinin paradigmasını ortaya koymak; aynı zamanda toplumda çocukluğun yeniden inşa sürecine karşlık vermek anlamına gelmektedir. Yukarıda özetlediğimiz Prout ve James'in yeni çocukluk sosyolojisi kuramı ile ilgili ortaya koydukları ana hatlar, çocuğun etken özneler olduğu anlayışı ile çocukluk sosyolojisine yönelik yapılacak çalışmalara katkı sağlamıştır. Nitekim yeni çocukluk 
sosyolojisinin bu perspektifinden hareket eden çalı̧̧malar, 1980'li yıllarla birlikte artmaya başlamıştır. Farklı çocukluklara ve çocuğun toplumsal aktör olma yönüne vurgu yapan ve çocuğu medya, tüketim, politika ve insan hakları gibi farklı temalarla ilintili bir şekilde ele alan çalışmaların yaygınlaşmasıyla yeni çocukluk sosyolojisi toplumda ve akademik çevrelerde yoğun ilgi kazanmıştır.

1980 sonrası süreçte ABD, İngiltere ve İskandinav ülkeleri başta olmak üzere gelişmiş ülkelerde yeni çocukluk sosyolojisinin ilerleme kaydetmesinde (Onur, 2019, s. 323) 1960'l1 yılların sonunda ortaya çıkan iki gelişmenin etkili olduğu söylenebilir. Bu gelişmelerden biri olan feminist hareket, akademik alanda üretkenliği ile kapsamlı ve derinlikli çocukluk çalışmalarına yön vermede başarılı olmuştur. Feminist hareket ilk olarak 1960'lı yıllarda ABD'de filizlenmiş ve 1970'li yıllarda Avrupa'da yaygınlaşmıştır. Kadın ve çocuk ilişkisinden yola çıkan feminist hareket, çocukların toplum ve aile içindeki konumlarıyla ilgili sorunların tartışılması ve çocukluğun yeniden tanımlanması noktasında belirleyici bir rol oynamıştır (Mayall, 2018, s.21-22). Feminist hareket, eleştirel bir bakış açısıyla aynı zamanda çocuk bakımı ile ilgili rol ve sorumlulukları ailede mevcut olan cinsiyet rolleri bağlamında sorgulamıştır. Buna göre, çocuk bakımı cinsiyetler arasında güç ilişkisine bağlanmış ve toplumsal cinsiyet rollerinin eşitsizliği nedeniyle çocuk bakımının daha çok anneye yüklendiği (Cockburn, 2010, s.35) hususuna dikkat çekilmiştir. Feminist sosyolojik yaklaşım, çocukların kendilerine özgü özellikleri ve deneyimleri olan bir grup olduğu anlayışını gündeme getirmiştir. Böylelikle söz konusu yaklaşım, eşitsiz konumlarına göndermede bulunarak çocukların cinsel istismar, aile içi şiddet, yoksulluk, hak gibi toplumsal sorunlar açısından ele alınmasına katkıda bulunmuştur (Oakley, 2003; Mullender ve diğerleri, 2002; Kitzinger, 2005). Bu çalışmalara örnek olarak Ann Oakley'in, "İlk ve Son Olarak Kadın ve Çocuklar: Çocuk ve Kadın Çalışmaları Arasında Paralellikler ve Farklılıklar (Women and Children First and Last: Parallels and Differences Between Children's and Women's Studies, 2003)" adlı çalışması verilebilir. Kadınların ve çocukların haklar konusunda benzer sorunlar yaşadıklarını vurgulayan Oakley, eserinde kadınların ve çocukların sosyal-kültürel bağlantılarını ele almış, her iki sosyal grubu yoksulluğu en yoğun yaşayan iki önemli grup olarak nitelendirmiştir. Feminist sosyolojik yaklaşımın kuramsal ve deneysel katkıları sayesinde bilimsel araştırmalara damgasını vuran toplumsal cinsiyet rolleri ve eşitsizlik vurgusu, yeni çocukluk sosyolojisinde farklı ve güncel tartışmaları da beraberinde getirmiştir. Yeni çocukluk sosyolojisini olgunlaştıran bir diğer gelişme ise çocuk hakları konusunda kaydedilmiştir. Birleşmiş Milletler Genel Kurulu tarafından 20 Kasım 1989 tarihinde kabul edilen ilk uluslararası sözleşme niteliğindeki Çocuk Haklarına dair Sözleşme ile ilgili tartışmalar zaman içerisinde çocuk istismarı, çocukların korunmasına yönelik kamu politikaları yaklaşımı ile çocukların toplumsal aktörler olarak ele alınması gerektiği yönündeki sosyolojik düşünceyi pekiştirmiştir (Ellis, 2010, s.191). Böylelikle çocuk hakları, çocuk istismarı, refah ve sosyal politikalar gibi toplumsal sorunlar çocukların toplumsal görünürlügünü etkin kılmıştır (Ercan, 2011, s.90). Yukarıda belirttiğimiz iki güncel gelişme, özellikle ABD'de ve İngiltere'de yeni çocukluk sosyolojisi çalışmalarına özgül bir karakter kazandırmıştır denilebilir.

Yeni çocukluk sosyolojisinin Dünya genelindeki gelişimine bakıldığında Mayall, (2018, s.31) yeni çocukluk sosyolojisine yönelik güncel konularla ilgili yapılan öncü çalışmaların daha çok $\mathrm{ABD}^{\prime}$ de gerçekleştirildiğini, kuramsal gelişmelerin önemli adımlarının ise Avrupa'da Qvortrup ve arkadaşları tarafından yapılan çözümlemelerle atıldığını belirtir. Jens Qvortrup, William A. Corsaro ve Michael Sebastian tarafından 
gerçekleştirilen Palgrave Çocukluk Çalışmaları El Kitabı (The Palgrave Handbook of Childhood Studies, 2009) adlı editöryal çalışma, çocuğu sosyal aktör olarak gören anlayıştan hareketle yeni çocukluk sosyolojisi bağlamında çocukların toplumdaki yerlerini sosyal, kültürel ve ekonomik açıdan sorgulamıştır. Söz konusu eserin yanı sıra yine Jens Qvortrup'un kaleme aldığı "İstatistik ve Sosyal Muhasebede Çocukların İfadesi: Çocukların Seslerini Duyurma Hakkı İçin Bir Savunma (A Voice for Children in Statistical and Social Accounting: A Plea for Children's Right to be Heard, 2005, s.83-103)" adlı çalışma, çocuğa yönelik bilimsel yaklaşımı ve konuları ele alışı itibariyle Avrupa'daki kuramsal çalışmalara yol göstermede etkili olmuştur. Mayall'ın (2018, s.31) verdiği bilgilere göre Avrupa'da çocukluk sosyolojisi alanındaki kuramsal araştırmalar daha çok Almanya'da; deneysel araştırmalar ise İngiltere'de gerçekleştirilmiştir. İngiltere'de çocuklara yönelik deneysel çalışmaların yapılmasında sivil toplum kuruluşlarının çocukları toplumsal bir sorun olarak gündeme getirmesinin büyük bir rolü olmuştur. Ayrıca İngiltere'de çocuk hakları ve refahına yönelik yetersiz imkânların varlığına yönelik getirilen toplumsal eleştiriler ile çocukları toplumsal bir aktör olarak ele alan "Children 5-16" programının ESRC (Ekonomik ve Sosyal Araştırma Konseyi) tarafından finanse edilmesi deneysel çalışmaların hız kazanmasında etkili olmuştur. Aşağıda detaylı bir şekilde ele alınacağı üzere İngiltere'de gerçekleştirilen araştırmalarda çocuk birey, sosyal bir aktör olarak daha çok insan hakları, eşitliksizlik ve yoksulluk gibi toplumsal sorunlarla ilişkisel bir biçimde ele alınmıştır. Çocuklarla ilgili genel bir değerlendirmede bulunan Berry Mayall'ın Çocukların Çocuklukları: Gözlenen ve Deneyimlenen (Children's Childhoods: Observed and Experienced, 2003) adl eserinde İngiltere'deki çocuk çalışmaları için yol gösterici kabul edebiliriz.

ABD'de çocuk ve çocukluğu araştıran yeni çocukluk sosyolojisi çalışmaları, 1990'lı yıllarla birlikte ağırlıklı olarak araştırma merkezlerinin ve çocukluk çalışmaları bölümlerinin üniversitelerde kurulmasıyla önemli bir ivme kazanmıştır. Bununla ilgili olarak ABD'de çocukluk sosyolojisine yönelik bilimsel araştırma yapan, öğretim veren "Amerikan Sosyoloji Derneği" ne bağlı çocuk ve gençlik bölümleri kurulmuştur (Bass, 2010, s.336, 343). Diğer taraftan 80'li ve 90'lı yıllarda nitel çalışmalar artmış, sosyal-yapısal sorunlara odaklanan kuramsal çalışmaların yaygınlaşmasıyla yeni çocukluk sosyolojisi ortaya çıkmıştır (Johnson, 2001, s.66). ABD'de akran kültürlerine yönelik etnografik çalışmalar popülerlik kazanmış ve sosyal eşitsizlik çalışmalarına ilgi artmıştır (Niederberger, 2010, s.372). ABD'de çocukluk çalışmalarında farklı çocukluk anlayışıyla çocuk istismarı, tehdit altındaki çocuklara yönelik çalışmalar ve bilimsel yayınlar artmaya başlamıştır. Bu yönde ABD'de yeni çocukluk sosyolojisi anlayışı çerçevesinde çocukların sosyal eşitsizlik deneyimlerini anlamaya yönelik eğitim merkezlerinde, yoksul mahallelerde ve okullarda kuramsal çalışmalar yürütülmüştür (Johnson, 2001, s.67). Söz konusu çalışmalarla ilgili literatür değerlendirildiğinde yoksulluk ve eşitsizlikler konusunun yoğunluklu ele alındığı göze çarpmaktadır. Bu konu ile ilgili olarak şu çalışmaları örnek verebiliriz: Sara Kimberlin ve Jill Duerr Berrick tarafından kaleme alınan "Yoksulluk Daha Ne Kadar? ABD'deki Kronik ve Geçici Çocuk Yoksulluğu (Poor for How Long? Chronic Versus Transient Child Poverty in the United States, 2015, s.141-158)" başlıklı makalede çocuk yoksulluğu toplumsal bir sorun olarak değerlendirilmektedir. Çalışmada, ABD'deki çocuk yoksulluğu diğer sanayileşmiş ülkelerle karşılaştırılmakta ve çocuk yoksulluğuna ilişkin demografik veriler sunulmaktadır. Ayrıca çocuk yoksulluğuna ilişkin politikaların uygulanması gerektiği ifade edilmektedir. Benzer şekilde Peter Gottschalk ve Sheldon Danziger tarafından gerçekleştirilen "Gelir Hareketliliği ve Amerikan Çocuklarının Yoksulluktan Çıkışı (Income Mobility and Exits From Poverty of 
American Children, 2001, s.135-153)" adlı çalışma, istatistiksel verilerden hareketle ABD'deki çocuk yoksulluğuna odaklanmaktadır. Samantha Friedman ve Daniel T. Lichter tarafından yapılan "Amerikan Çocukları Arasında Mekânsal Eşitsizlik ve Yoksulluk (Spatial Inequality and Poverty Among American Children,1998, s.91-109)" adlı çalışma, 1990 yılı ABD nüfus sayımı verilerine dayanarak mekânsal eşitsizlik ve yoksulluk kavramlarına odaklanmıştır. Söz konusu çalışmada çocuk yoksulluğunun mekânsal dağılımlar açısından farklılık gösterdiği vurgulanmış, ailenin gelir ve istihdam durumu ile sosyo-ekonomik refah düşüklügünün bu farklılığa neden teşkil ettiği sonucuna varılmıştır. Duncan Lindsey'e ait Çocuk Yoksulluğu ve Eşitsizlik: Amerikan Çocukları İçin Daha İyi Bir Gelecek Sağlamak (Child Poverty and Inequality: Securing a Better Future for America's Children, 2009) adlı eserde ise ABD'nde çocukların toplumsal konumu, yine yoksulluk ve eşitsizlikler bağlamında ele alınmıştır. Lindsey bu eserinde $\mathrm{ABD}^{\prime}$ de yaşayan Afro-Amerikalı ve İspanyol gençleri ile Beyaz ve Asyalı gençlerin çocukluk deneyimlerini karşılaştırmalı bir şekilde analiz etmiştir.

İngiltere'de çocuk ve çocuklara yönelik sosyolojik araştırmalar, çocuk ve gençlik araştırma merkezlerinin yanı sıra, sosyoloji bölümlerinde ve uygulamalı mesleklerin öğretim programlarında yer almıştır. Diğer taraftan çocukluk sosyolojisi araştırmaları, çocukluğun yerel/kültürel/bölgesel açıdan farklılığı kuramının ortaya konulması ile birlikte İngiltere'de "yoksulluk, boşanma, iş, sağlık gibi alanlardaki toplumsal sorunlar" çerçevesinde ele alınmaya başlanmıştır (Niederberger, 2010, s.372) ve bu konudaki çalışmalar literatürü zenginleştirmiştir. İngiltere'de çocukluk çalışmalarına ilişkin konferanslar, seminerler, etkinlikler ve yayınlar çocukluk sosyolojisine katkı sağlamıştır (Ellis, 2010, s.196). İngiltere'de halen üniversite ve yüksekokullarda multidisipliner ya da disiplinlerarası çocukluk araştırmaları dersleri verilmekte (Mayall, 2018, s.49) ve bu yeni alana yönelik ilgi giderek yoğunluk kazanmaktadır. İngiltere'de çocukluk sosyolojisine katkı sağlayan çalışmalara örnek olarak verdiğimiz yukarıda adı zikredilen Çocukların Çocuklukları: Gözlenen ve Deneyimlenen (Children's Childhoods: Observed and Experienced, 2003) adlı editöryal çalışmada özellikle Virginia Morrow'un "Sorumlu Çocuklar mı? Günümüz Britanya'sında Çocukların Okul Dışı İş ve İstihdamı (Responsible Children? Aspects of Children's Work and Employment Outside School in Contemporary UK, 2003, s.128-143) adlı makalesi işgücü piyasasında çalışan çocuklar konusunda dikkate değer niteliktedir. İngiltere'de 11-16 yaş aralığındaki çocukların iş yaşamındaki durumunu araştıran bu çalışma, nitel yöntem izlenerek gerçekleştirilmiştir. Çocukların sosyal aktör olduğu fikrinden hareket eden söz konusu makale, çocukların öznel yaşantılarından yola çıkarak onların iş deneyimlerine odaklanmaktadır. Çocuk ve yoksulluk ilişkisini sorgulayan çalışmaya göre çocuğu işgücü kaynağı olarak gören toplumlarda norm ve değerlerdeki farklılıklar, çocukların aynı zamanda iş yaşamını değişik biçimlerde deneyimlemelerine de yol açabilmektedir.

İngiltere'de yoksulluk, eşitsizlik, sosyal refah ve politikalar bağlamında yeni çocukluk sosyolojisine katkı sağlayan çalışmalara şu eserleri ayrıca örnek olarak verebiliriz: Paul Daniel ve John Ivatts tarafından kaleme alınan Çocuklar ve Sosyal Politika (Children and Social Policy, 1998) adlı eserde çocuk refahı konusu yoksulluk, çocuk istismarı ve eğitim bağlamında ele alınmıştır. Jane Pilcher ve Stephen Wagg tarafından yayınlanan Thatcher'in Çocukları mı? 1980 ve 1990'larda Siyaset, Çocukluk ve Toplum (Thatchers Children? Politics, Childhood and Society in the 1980s and 1990s, 1996) adlı eserde çocuğun yapısal bir varlık olduğu anlayışından hareketle çocuk hakları sorunu ele alınmıştır. Martha S. Hill ve Stephen P. Jenkins tarafından kaleme alınan "Britanyalı Çocuklarda Yoksulluk: Kronik mi, Geçici mi? (Poverty Among British Children: Chronic or Transitory?, 2001, s.174-195)" başliklı 
makalede uluslararası çalışmalar ve verilerden hareketle çocuk yoksulluğu ele alınmıştır. Tess Ridge tarafından gerçekleştirilen Çocuk Yoksulluğu ve Sosyal Dışlanma: Bir Çocuğun Perspektifinden (Childhood Poverty and Social Exclusion: From a Child's Perspective 2002) adlı eserde ise yoksul çocukların toplumsal yaşama katılımlarında aktif özne olduklarının altı çizilmiş, 10-17 yaş aralığında bulunan çocukların yoksulluk, eşitsizlik, sosyal dışlanma gibi süreçleri nasıl deneyimlediklerine değinilmiştir. İngiltere'de çocuk yoksulluğunu ele alan bir başka çalışma Nick Axford'a ait Çocuk Refahın Keşfetme Kavramları: Çocuk Hizmetleri Üzerine Çıkarımlar (Exploring Concepts of Child Well-being: Implications for Children's Services, 2008) adlı eserdir. Çocuk ve çocukların ailelerine yönelik gerçekleştirilen deneysel nitelikteki çalışmada yoksulluk, hak, sosyal dışlanma gibi faktörlerin çocuklar tarafından nasıl deneyimledikleri hususu incelenmekte ayrıca çocuk hakkı, çocukların ihtiyaçları, yoksulluk, yaşam kalitesi, sosyal dışlanma, çocuk refahı, çocuk hizmetleri gibi konular üzerinde durulmaktadır. Londra'da orta derecede yoksul olan, etnik çeşitliliğe sahip konutlarda yaşamak zorunda kalan 689 çocuk ve aileleri ile gerçekleştirilen bu deneysel çalışmada özellikle refah politikalarının gelişiminin İngiltere'de önemli bir kamu politikası söylemi haline geldiği belirtilmektedir.

Almanya'daki çalışmalara bakıldığında ise çocukluk sosyolojisinin; politik gelişmelere bağlı olarak çocuklukta yaşanan değişmelerin konu edilmesi suretiyle yaygınlaştığı görülmektedir. Almanya'da 1960 ve 1990'lı yıllarda yaşanan ekonomik gelişmeler ve politik süreçlerin etkisiyle çocukların gündelik yaşamdaki durumu ve sosyal konumu üzerindeki endişeler sorgulanmaya başlamıştır. Ayrıca çocuğun toplumsal aktör olarak ele alınması, çocukların günlük hayatlarında belirginleşen yeni çocukluk özelliklerine yönelik deneysel çalışmalar, Almanya'daki yeni çocukluk sosyolojisi çalı̧̧malarını hızlandırmıştır. 1997 yılında Almanya Sosyoloji Derneği tarafından "Çocukluk Sosyolojisi" bölümü kurulmuş ve uluslararası konferanslardan yararlanılarak yeni çocukluk sosyolojisi çalışmaları ülkede tartışılmaya başlanmıştır (Zeiher, 2010, s.293-295). Almanya'da yeni çocukluk sosyolojisine katkı sağlayan öncü isimlerden biri, yukarıda adını daha önce zikretmiş olduğumuz Jens Qvortrup'tur. "İstatistik ve Sosyal Muhasebede Çocukların İfadesi: Çocukların Seslerini Duyurma Hakkı İçin Bir Savunma (A Voice for Children in Statistical and Social Accounting: A Plea for Children's Right to be Heard, 2005)" adlı çalışmasında çocuğu bir sosyal aktör olarak gören Qvortrup, çocukların toplumda yasal haklarının ne oranda gözetildiği konusunu irdelemiş, refah devletinde toplumsal görünürlük ve onaylanmışlık biçimlerini ele almıştır. Almanya'da 1980 sonrası çocukluk sosyolojisine güncel veriler ışı̆̆ında katkı sağlayan çalışmalardan biri, Christian Schluter tarafından kaleme alınan "Almanya'da Çocuk Yoksulluğu: Yönelimler ve Süreklilik (Child Poverty in Germany: Trends and Persistence, 2001, s.154-173)" başlıklı makaledir. Schluter, çalışmasında 1983-1995 yılları arasındaki sosyo-ekonomik verilerden hareketle Almanya'daki Alman ve göçmen çocukların ekonomik durumunu yoksulluk bağlamında sorgulamaktadır. Sabine Andresen, Susann Fegter, Klaus Hurrelmann, Monika Pupeter ve Ulrich Schneekloth tarafından kaleme alınan "Almanya'da Çocuk Yoksulluğu: Kavramsal Görünümler ve Temel Bulgular (Child Poverty in Germany: Conceptual Aspects and Core Findings, 2015, s.127-140)" başliklı makalede, yine istatistiksel verilerden hareketle Almanya'daki çocuk yoksulluğunun toplumsal sonuçları gözler önünde serilmiştir.

Özellikle ABD, Almanya ve İngiltere'de çocukluk sosyolojisine katkı sağlayan yeni çocukluk sosyolojisi çalı̧̧maları, diğer ülkelerin çocukluk sosyolojisi anlayışına da yön vermiştir. Yeni çocukluk sosyolojisi eğilimiyle çocukların toplumsal aktör olarak ele 
alınabileceği ve toplumsal bir yapı olduğu fikri, yeni çocukluk sosyolojisinin popülerleşmesini sağlamıştır. İtalya'da 1990'lı yıllardan itibaren çocuk birey, sosyal aktör olarak tartışılmaya başlanmıştır. Söz konusu tartışmalar kapsamında yeni çocukluk anlayışı çocuk hakları, vatandaşlık, sosyal politikalar, çokkültürlülük gibi konular çerçevesinde şekillenmiştir (Baraldi, 2010, s.272, 274). Benzer şekilde Fransa' da çocukluk sosyolojisi 1990’lı yıllarda sosyalizasyon paradigmasına yönelik eleştiriler ile gelişmeye başlarken, "çocukluk sosyolojisi" kavramı 1998 yılında ilk kez Eğitim Sosyolojisi dergisinde yer bulmuştur (Sirota, 2010, s.250, 252). Avustralya'da yeni çocukluk sosyolojisi çalışmaları İngiltere, Fransa, Almanya gibi ülkelerdeki çalışmaların etkisiyle şekillenirken Finlandiya'da ise yeni çocukluk sosyolojisi refah politikasında yaşanan değişimler, çocuk haklarının gelişimi (Krieken, 2010, s.232; Strandell, 2010, s.165,172) gibi güncel konu ve sorunların etkisiyle gelişme fırsatı bulmuştur.

Geleneksel çocukluk sosyolojisinden farklı olarak yeni çocukluk sosyolojisi alanında dikkati çeken hususlardan biri, ulus ölçekli çalışmaların yanı sıra karşılaştırmalı bakış açısı ile üretilen uluslararası ölçekli çalışmaların yoğunlukta olmasıdır. Son yıllarda bu özelliği taşıyan önemli editöryal çalışmaların yapıldığı gözlenmektedir. Bu çalı̧̧malarla ilgili birkaç örnek şu şekilde verilebilir: Almanya, ABD, İtalya ve Avustralya'da çocukların toplumdaki yerini ve maruz kaldıkları sorunları ele alan önemli çalışmalardan biri, Elizabeth Fernandez, Anat Zeira, Tiziano Vecchiato ve Cinzia Canali'nin editörlüğünde yayınlanan Çocuk ve Aile Yoksulluğu Üzerine Teorik ve Ampirik Anlayışlar: Uluslararası Perspektifler (Theoretical and Empirical Insights into Child and Family Poverty: Cross National Perspectives, 2015) adli eserdir. Söz konusu ülkelerdeki çocuklara dair verilerden hareketle bu eserde çocuk ve aile yoksulluğu, çocuk refahı, çocuk hakları ve sosyal dışlanma konuları karşılaştırmalı bir bakış açısıyla analiz edilmiştir. Bir diğer örnek çalışma, Bruce Bradbury, Stephen P. Jenkins ve John Micklewright'ın editörlüğünde gerçekleştirilen Sanayileşmiş Ülkelerde Çocuk Yoksulluğunun Dinamikleri (The Dynamics of Child Poverty in Industrialised Countries, 2001) adlı eserdir. Bu çalışmada İngiltere, Amerika, Almanya, İlanda, Rusya gibi yirmi beş ülkede ve yedi sanayileşmiş ülkelerin çocuk ve yoksulluk konusundaki görünümleri istatistiki veriler ışığında ele alınmaktadır. Carol Camp Yeakey ve Jeanita W. Richardson'ın editörlüğünde hazırlanan Cefa Çeken Küçük Çocuklar: Çocuk Yoksulluğu ve Kamu Siyasetinin Ulusal ve Uluslararası Boyutlar (Suffer the Little Children': National and International Dimensions of Child Poverty and Public Policy, 2006) adlı eserde ise genel itibariyle çocuk yoksulluğu üzerinde durulmakla birlikte, çalışmada yer alan makalelerde eğitim reformu, şiddet, demokrasi, sosyal refah politikaları ve sokak çocukları konuları ayrıntılı şekilde ele alınmaktadır.

Tarihsel süreçte sanayileşme, kapitalizm, çocuk hakları kavramının gelişimi, küreselleşme ve ideolojinin etkileri, politik ve ekonomik gelişmeler, sosyal politikaların gelişimi, hukuksal gelişmeler, refah politikalarının gelişimi, medya endüstrisinin etkisi gibi gelişmeler, çocuk sorunlarını ve çocuk haklarını gündeme getirmiştir (Franklin, 1993; Ercan, 2011; James ve Prout, 2005; Mayall, 2001; Postman, 1995; İnal, 2007b). Bu gelişmeler çocuğun toplum içinde ve çocukluk sosyolojisi kapsamında ele alınmasına üç farklı şekilde katkı sağlamıştır. İlk olarak, cinsel istismar ve şiddet gibi toplumsal sorunlara maruz kalan kategoriler olarak çocukların toplumsal sorunları görünürlük kazanmıştır. İkinci olarak, özellikle çocuk hakları kavramı, sosyal politikalar ve refah politikalarının gelişimi ile birlikte çocuklar sosyal eşitsizlik bağlamında sorgulanmıştır. Üçüncü olarak, yeni çocukluk sosyolojisinin görünür kıldığı işçi, göçmen, yoksul gibi farklı çocuk grupları haklar ve eşitsizlikler bağlamında ele alınmaya başlanmıştır. Dolayısıyla bütün bu toplumsal 
gelişmeler, çocuğun toplum içindeki yerini, statüsünü, görünürlüğünü ve eylemliliğini belirlemede yönlendirici olmuştur. Çocukların toplumdan nasıl etkilendikleri ve toplumu nasıl etkiledikleri konusu, çocukluk sosyolojisinde çocukların toplumsal olarak nasıl inşa edildiğinin keşfedilmesini sağlamıştır. Bu gelişmelerle birlikte çocuğun toplum içindeki yeri ve önemine ilişkin farkındalık, çocukluk sosyolojisi çalışmalarını yeniden biçimlendirmiş, çocuk ve çocukluk temaları; küreselleşme, eşitsizlik, göç, sosyal uyum, sosyal dışlanma, kimlik, savaş, açlık gibi güncel toplumsal konular bağlamında sorgulanma imkânına kavuşmuştur.

Tablo 1. Geleneksel Çocukluk Sosyolojisi ve Yeni Çocukluk Sosyolojisine İlişkin Bir Karşılaştırma

\begin{tabular}{|l|l|l|}
\hline & $\begin{array}{l}\text { Geleneksel Çocukluk } \\
\text { Sosyolojisi }\end{array}$ & Yeni Çocukluk Sosyolojisi \\
\hline Çocukluk Anlayışı & Evrensel & $\begin{array}{l}\text { Evrensel, Yerel/Kültürel } \\
\text { Açıdan Farklılık }\end{array}$ \\
\hline Sosyalizasyon Anlayışı & $\begin{array}{l}\text { Çocuk pasiftir } \\
\text { (Yapıdan faile tek yönlü } \\
\text { bir ilişki vardır) }\end{array}$ & $\begin{array}{l}\text { Çocuk aktiftir } \\
\text { (yapı-fail etkileşimi vardır) } \\
\text { (Yorumsal yeniden üretim } \\
\text { kavramı ön plandadır) }\end{array}$ \\
\hline Yöntem & $\begin{array}{l}\text { Ağırlıklı nicel yöntemler } \\
\text { kullanılır }\end{array}$ & $\begin{array}{l}\text { Ağırlıklı nitel yöntemler olmak } \\
\text { üzere hem nitel hem de nicel } \\
\text { yöntemler kullanılır }\end{array}$ \\
\hline Kuram, İlke ve Yaklaşımlar & $\begin{array}{l}\text { Pozitivizm, Psikolojik } \\
\text { Determinizm, Yapısal } \\
\text { İşlevselcilik }\end{array}$ & $\begin{array}{l}\text { Pozitivizm, Etnometodoloji, } \\
\text { Yorumlayıcı yaklaşım, Sosyo- } \\
\text { kültürel determinizm, } \\
\text { Yapılandırmacı } \\
\text { (İnşacı)Yaklaşı, } \\
\text { Yapıçözümcü Yaklaşım, } \\
\text { Sembolik Etkileşimcilik }\end{array}$ \\
\hline Temalar & $\begin{array}{l}\text { Küreselleşme, Kimlik, Çevre, } \\
\text { Sosyal dışlanma, Kentleşme, } \\
\text { Suç, Aile, Eğitim, Politika, } \\
\text { Savaş, Sosyal Medya, Sivil } \\
\text { Toplum }\end{array}$ \\
\hline & $\begin{array}{l}\text { Sosyalizasyon, Eğitim, } \\
\text { Aile, Suç, İşçi, Göç, } \\
\text { Medya }\end{array}$ & \\
\hline
\end{tabular}

Mevcut literatür taramasına ilişkin değerlendirmelerden hareketle Tablo 1'de geleneksel çocukluk sosyolojisi ile yeni çocukluk sosyolojisine ilişkin şematik bir karşılaştırma yapılmıştır. Tablo incelendiğinde geleneksel çocukluk sosyolojisinin çocuğu, yaş ve biyolojik özellikler ile belirlenen evrensel bir algılayışla ele aldığı, yeni çocukluk sosyolojisinin ise dünya üzerinde yaşamlarını farklı deneyimleyen çocukların varlığından hareketle farklı çocukluk algılayışlarını da kabul ettiği söylenebilir. Geleneksel çocukluk sosyolojisi, çocuğun sosyalizasyonu sürecinde toplum, sosyal çevre, aile ve devlet ile etkileşiminde çocuğa edilgen bir rol yüklemiştir. Geleneksel çocukluk sosyolojisi anlayışından farklı olarak yeni çocukluk sosyolojisi, yapı-fail ilişkisinden hareketle çocukları eyleyen, değişime katkı sağlayan bireyler olarak ele almış, böylece hem bölgesel hem de kültürel açıdan çocukların farklı yaşam tecrübelerine sahip olduklarını vurgulamıştır. 
Her iki çocukluk sosyolojisinde yöntem, kuram, ilke ve yaklaşımlar, dünya/bölge/ülke bazlı toplumsal değişmeler ve bu toplumsal değişmelere paralel olarak çocuğun değişen toplumsal değerine göre kendi içerisinde farklılıklar sergilemektedir. Geleneksel çocukluk sosyolojisi ile yeni çocukluk sosyolojisi arasındaki temel farkı belirleyen husus, çocuk kavramına ilişkin tanımlama biçimleri ve çocukluk anlayışındaki farklılıklardır. Büyük ölçüde pozitivist yaklaşımdan hareket eden geleneksel çocukluk sosyolojisi çocukları daha çok bir "nesne" gibi görürken buna karşılık yeni çocukluk sosyolojisi, çocuğun "aktör" yönüne dikkat çekmiştir. Yeni çocukluk sosyolojisi, çocukların toplumsal ilişkilerde ve kültürel yaşantılarda etkin olabileceklerini ve bağımsız roller üstlenebileceklerini ileri sürmüştür. Bu nedenden ötürü yeni çocukluk sosyolojisi, çocukların kendi deneyimlerini nasıl içselleştirdiklerinin ve tecrübe ettiklerinin anlaşılması noktasında yorumlayıcı yaklaşımı ve etnometodolojiyi gerekli görmüştür. Söz konusu yaklaşımların sayesinde çocukların yaşam dünyalarının inşa yolları ve anlamlandırma biçimlerine ilişkin bilme biçimleri de böylelikle mümkün olabilecektir. Yine Tabloda görüldüğü üzere her iki sosyoloji anlayışının çocuğa ilişkin bilimsel bilgi üretim sürecinde değindikleri ana temalar da farklılık göstermektedir. Geleneksel anlayıştan farklı olarak yeni çocukluk sosyolojisi, 1980 sonrası süreçte dünya genelinde başgösteren insan hakları, eştsizlikler ve sosyal politikalar ile ilgili gelişme ve yeni eğilimlere istinaden hem makro hem de mikro düzeyli bakış açısı gütmüş, temalarını (küreselleşme, kimlik biçimleri, cinsel istismar, göç ve göçmenlik, savaş ve kıtlıklar, sivil toplum, sosyal medya, sosyal refah ve uyum politikaları vs.) bu bağlamda irdeleme yolunu tercih etmiştir.

Çocukluk sosyolojisinin kuramsal temelleri dünya üzerinde yukarıda belirttiğimiz şekilde oluşurken, Türkiye'de çocukluk sosyolojisinin daha geç bir tarihte gelişmeye başladığını ifade edebiliriz. Şüphesiz belirttiğimiz ülkelerde olduğu gibi Türkiye'de de çocukluk sosyolojisinin ön hazırlık evresi, farklı disiplin ve bakış açıları ile üretilen çocukluk çalışmaları sayesinde mümkün olabilmiştir. Osmanlı döneminin son yılları ve Cumhuriyet'in ilk yıllarında Münif Paşa, Ziya Gökalp, İsmayıl Hakkı Baltacıŏ̆lu (Eraslan, 2015, s.25) gibi dönemin aydınları, eserleri ile çocukluk çalışmalarına dolaylı olarak katkı sağlayan düşünürlere örnek verilebilir. Münif Paşa Mecmua-i Fünun dergisinde yayınlanan makalesinde çocuk eğitimi ve çocuğun toplum için önemi konularını ele almış, çocuğun yetiştirilmesinde toplumun ne kadar bilinçli olduğunu sorgulayarak çocuk-toplum ilişkisine değinmiştir (Doğan, 2000, s.222-223). İsmayıl Hakkı Baltacıŏlu da eğitim sosyolojisine yönelik görüşleri ile çocukluk çalışmaları alanına katkı sağlamıştır. Eğitimin temel amacını, topluma faydalı bireyler yetiştirmek şeklinde ifade eden Baltacıoğlu, çocukların toplumun dâhil olduğu zaman ve koşullara uygun olarak yetiştirilmesi gereğini vurgulamıştır (Kaçmazoğlu, 2013, s.56-57). Burada Baltacioğlu'nun üzerinde durduğu temel husus, çağın değişen koşulları karşısında eğitimin topluma ve çağa uygun işlevlerle donatılmış olmasıdır. Sosyolog Ziya Gökalp ise toplumun kültürünün yeni kuşaklara aktarılmasında eğitimin rolüne dikkat çeker. Gökalp, ancak milli kültürü içselleştirmek yoluyla çocukların gerçek kişiliklere sahip olabileceğini (Zabun, 2019, s.117-118) ileri sürer ve eğitimin sosyalleştirici işlevini ön plana çıkarır. Cumhuriyetin kuruluş yıllarında Türkiye'de gerçekleşen köklü değişimin tarihsel ve sosyolojik sonuçları; çocuğun aile, devlet ve din kurumları çerçevesinde "ideal Türk çocuğu" nun özellikleri, tarihiyle olan ilişkisi, terbiye, milli duygular gibi açılardan tartışılmasına neden olmuştur (İnal 2007a, s.41; İnal, 1999, s.200-201). Türkiye'de Şirin'in $(2019$, s.34) ifadesiyle ilk dönem çocukluk çalışmaları, daha çok çocuk anlayışı ve yetişkin algısından hareketle ilerlemiştir. Çocuğun toplumsal bir aktör olarak 
hem toplumu nasıl etkilediği hem de toplumdan nasıl etkilendiği yönündeki karşılıklı girift ilişki sorgulanmamıştır.

Çocukluk çalışmaları ile ilgili kapsamlı bir birikimin olmasına karşılık Türkiye'de çocukluk sosyolojisi alanında zengin bir literatürün varlığından henüz söz edemeyiz. Özellikle son yıllarda çocukluk sosyolojisine katkı sağlayıcı çalışmaların hız kazandığı görülmektedir. Çocuğu sosyolojik boyutta irdeleyen söz konusu çalışmalar, çocuğa yönelik oluşturulan kuramları tartışmakta ve bu kuramların yol göstericiliğinde çocuğun karşılaştığı toplumsal sorunlara ilgiyi güncel kılmaktadır. Çocukluğu eğitim, toplumsal değişme, aile, din, toplumsal sorunlar bakımından ele alan çalışmaların başında Mahmut Tezcan'ın Çocuk Sosyolojisi (2017) adlı eseri zikredilebilir. Tezcan, bu çalışmasında çocuk ve çocukluk konusunun toplumun ögeleriyle ilişkili yanlarına değinmektedir. Toplumsal değişmeye bağlı olarak televizyon, bilgisayar gibi kitle iletişim araçlarının çocuklar üzerindeki etkisini ele alan söz konusu eser, boşanma, çocuk istismarı, yoksulluk, suçluluk gibi toplumsal sorunların çocuk üzerindeki olumsuz etkilerini sorgulaması, çocuk ve şiddet arasındaki ilişkiyi irdeleyerek Türkiye'deki çocuk cinayetlerine dikkat çekmesi bakımından önemlidir. M. Tezcan, bir diğer eseri olan Eğitim Sosyolojisi (1985)'nde çocuğun sosyalizasyonunu ve eğitim sürecini ele alarak çocukluk çalışmalarına sağlamıştır.

Son yıllarda çocukluk araştırmalarından farklı içerikte çocukluk sosyolojisi çizgisinde sayılabilecek önemli yayınlardan biri, Cevat Özyurt tarafından kaleme alınmış olan "Çocukluk Sosyolojisi: Bir Giriş Denemesi (2017)" adlı çalışmadır. Bu çalışma, çocukluk sosyolojisine yönelik paradigmaları, çocukluk teorileri ve farklı tarihsel dönemlerdeki çocukların görünümlerini ele alması açısından dikkate değer niteliktedir. Özyurt, çalışmasında çocukluk sosyolojisinin aktif ve pasif olmak üzere iki yaklaşım biçimini ele almakta, John Locke, Jean J. Rousseau, Emile Durkheim gibi düşünürlerin sosyal teorilerinde çocukluk yaklaşımlarına değinmekte ve aristokrat, burjuva, işçi, köy aileleri gibi farklı aile tiplerinde çocuğun durumunu sorgulamaktadır. Çocukluk sosyolojisi alanında aydınlatıcı nitelikte bir diğer çalışma, Aylin Dikmen Özarslan'ın Çocuk ve Çocukluk Sosyolojisi (2016) adlı eseridir. Özarslan, çocuk ve çocukluk ile ilgili teorileri, çocukluk sosyolojisinin kapsamını, çocuk çalışmalarının kadın çalışmalarıyla ortak yönlerini ele almak suretiyle çocukluk sosyolojisi literatürüne katkı sağlamaktadır. Eğitim sosyolojisi ve çocukluk sosyolojisi alanında çalışmalar yapan Levent Eraslan ise Farklı Perspektiflerden Çocuk ve Çocukluk Sosyolojisi (2015) adlı eserde çocukluk sosyolojisinin önemine dikkat çekmekte, bu alt bilim dalının sosyolojinin diğer alt bilim dalları ile olan ilişkine değinmektedir.

Yukarıda değindiğimiz örnek çalışmaların yanı sıra Türkiye'de çocukluk sosyolojisi bilimine aile sosyolojisi alanında yazılmış eserlerin de katkı sağladığını söyleyebiliriz. Örneğin, editörlüğünü Kadir Canatan ve Ergün Yıldırım'ın yaptı̆̆ı Aile Sosyolojisi (2013) adlı eser, aile ve çocuk ilişkisi, çocuk suçluluğu ve çocuk suçluluğunun önlenmesine yönelik sözleşmeleri, Dünyada ve Türkiye'de çocukluk algısı gibi konuları ele almak suretiyle ilgili literatüre katkı sağlamaktadır. Bu editöryal çalışmada Ramazan Yelken'in "Çocuk Suçluluğunu Önlemenin Temeli Olarak Uluslararası Çocuk Sözleşmeleri ve Aileye Verilen Önem (2013)" başlıklı çalışması, çocuk suçluluğunun önlenmesinde politikaların önemi ve oluşturulması hususuna dikkat çekmektedir. Aynı çalışmada çocuk suçluluğunun bireysel, toplumsal ve ailesel nedenlerinin analizi yapılmakta, çocuk suçluluğunun önlenmesinde ailenin rolü ve hukuksal sözleşmeler tartışılmaktadır. Aynı editöryal çalışmada Kadir Canatan “Dünya'da ve Türkiye'de Çocuk Algıları ve Cinsiyet Öncelikleri (2013)" adlı 
çalışmasında toplumsal-kültürel farklılıktan hareketle aile değerleri ve farklı çocukluk algılarını incelemiştir. Cinsiyet ayrımcılığı sorununa da işaret eden Canatan, çalışmasında çocuğun gelişiminde ailenin rolü, ailenin değerleri ve çocuk algısı arasındaki ilişkiye değinmekte, çocuk suçluluğunun göç, uyuşturucu gibi toplumsal nedenleri ve boşanma gibi ailevi nedenlerini incelemektedir. Cinsiyetlerin farklı ülkelerde ne şekilde kabul gördüğü hususuna değinmesi, cinsiyete önem veren ve vermeyen ülkelerde cinsiyete etki eden özellikleri tartışması suretiyle söz konusu eser, çocuk ve kültürel değerler konusuna farklı bir boyut kazandırmıştır.

Çocuk kültürü, çocuk hakları ve eğitim sosyolojisi alanına katkı sağlayan İsmail Doğan, Türk Aile Sosyolojisi (2016) adlı eserinde Türk aile yapısı hakkında bilgiler vermiş, çocuk ve aile ilişkisinden hareketle çocuk sorunlarını gündeme getirmiştir. Çocuk hakları ve kültürünün nasıl geliştiği, çocuk gelin kavramının dünyada ve Türkiye'de nedenleri, çocuğa yönelik sosyo-pedagojik sorunlara ilişkin çıkarsamaları ile eser, çocukluk sosyolojisine katkı sağlayıcı değerdedir. Diğer taraftan çocuk suçluluğu alanında yazılmış bazı eserlerin de çocukluk araştırmalarına katkı sağladığını söyleyebiliriz. Örneğin Haluk Yavuzer'in Çocuk ve Suç (2019) adlı eseri, çocuk suçluluğuna ilişkin kuramsal ve hukuksal bilgileri aktarmanın yanı sıra çocuk suçluluğunda etkili olan temel etkenleri evrensel ve yerel boyutlarıyla birlikte ele almaktadır.

Yukarıda belirttiğimiz bilgilerden hareketle denilebilir ki Dünya'da ve Türkiye'de çocukluk sosyolojisi, sosyoloji bilimi çatısı altında hâlâ gelişmeye devam eden bir alt disiplin dalıdır. 1980'li yıllardan itibaren yeni çocukluk sosyolojisinin kuramsal ve deneysel temellerinin belirlenmesiyle çocukluk sosyolojisi alanı, yeni bir metodolojik anlayış ve kuramsal temel kazanmıştır. Toplumun farklı kesimlerine ve bireylerine olan etkileri açısından bakıldığında kapitalizm, işgücü piyasası, insan hakları, sağlık politikaları, sosyal medya, göç, uyum, kimlik ve eşitsizlik gibi Dünya'da ve Türkiye'de halen güncelliğini sürdüren birçok toplumsal sorunun çocuklar üzerindeki etkilerine değinen çalışmaların giderek artış kaydetmesi, şüphesiz yeni çocukluk sosyolojisi alanının olgunlaşmasında etkili olacaktır.

\section{SONUÇ}

Sosyoloji biliminde çocuk, uzun yıllar aile sosyolojisi ve eğitim sosyolojisi içinde sosyalizasyon konusu kapsamında ele alınmıştır. Çocuklar, sosyoloji disiplininde sokakta çalışan çocuk, işçi çocuk, yoksul çocuk, göç, sosyal uyum konuları etrafında tartışılagelmiştir. Geleneksel sosyolojik araştırmaların gölgesinde olgunlaşan çocukluk sosyolojisi, yeni çocukluk sosyolojisinin gelişmesiyle çocuğa yönelik disiplinlerarası bakış açısını gerekli kılmış ve çocukların toplumsal bir aktör olarak ele alınmasının önemini gündeme getirmiştir. Yeni çocukluk sosyolojisinin gelişimine bağlı olarak çocukların "sosyal aktör" olarak ele alınması yakın dönemde kabul gören bir eğilim olmuştur. Yeni çocukluk sosyolojisinin farklı çocukluk biçimlerine ve çocuğun sosyal aktörlüğüne ilişkin vurgusu, çocukların küreselleşme, medya, çocuk hakları, sosyal dışlanma, mahremiyet, şiddet, kültür, eşitsizlik, politika, sivil toplum, toplumsal cinsiyet, sağlık, kuşaklararası farklılık, çevre gibi konular kapsamında tartışılması gereğini ortaya koymaktadır. Yeni çocukluk sosyolojisi alanında yapılacak olan çalışmalar, çocukların sosyolojik konular kapsamında ele alınmasına yönelik ilgi ve gereksinimi de artıracaktır. Nitekim literatürde çocukluk sosyolojisi çalışmaları, küreselleşme, eşitsizlik, toplumsal cinsiyet, çevre vb. konular bağlamında farklı ülkelerin çocukluk sosyolojisi çalışmalarında yer bulmaya başlamıştır. 
Genel olarak bakıldığında Türkiye'de çocuk ve çocukluk ile ilgili çalışmaların daha çok suç sosyolojisi, eğitim sosyolojisi ve aile sosyolojisi alanındaki araştırmalar kapsamında gerçekleştirildiği görülmektedir. Gerek Türkiye' de gerekse dünyada çocukluk sosyolojisinin tarihsel gelişimini, çocuğa yönelik kuramları ve deneysel araştırmaları ele alan kaynakların sınırlı sayıda olduğu görülmektedir. Doğrudan çocukluk sosyolojisi kapsamında değerlendirilecek çalışmaların sayısal azlığı, Türkiye'de "yeni çocukluk sosyolojisi"nin henüz yeni gelişen bir alt alan olduğuna işaret etmektedir.

\section{SUMMARY}

This study aims to analyze the developmental course of sociology of childhood which has evolved from "traditional" to "new" sociology of childhood, also how new trends and theoretical foundations are shaped for children. The study, which is based on the literature review and evaluation, has a theoretical quality in accordance with its purpose.

Looking generally at the researches on children in the social sciences, it can be observed that these studies are covered under the title of "childhood studies" or "childhood researches". In the 20th century, the first branch of social science dealing with the subject of children was the history of childhood. Research in this area will feed childhood sociology in the next period.

The development of sociology of childhood in sociology had a chance to manifest itself quite the late period. When the literature on the subject is examined, it is seen that the studies in this field intensified in the 1970s. From 1980s onward, the subject of child and childhood has drawn attention as a field of study in sociology and anthropology, as well as the sciences such as psychology and pedagogy.

Covering on the development process and theoretical foundations of sociology of childhood, it can be seen that there are two different approaches on sociology of childhood. The first is the traditional (classical) understanding of sociology of childhood, which was also the basis of sociology of childhood in the pre-1980 period. The second is the "new sociology of childhood" studies that have developed from the 1980s on. Traditional sociology of childhood has addressed the child in the context of the socialization paradigm based on the unilateral causality principle. On the contrary, according to the new sociology of childhood, the child is a social entity that can be examined in "sociological value" like an adult person per se. Being active in society, the child individual is in a process of mutual interaction with society. According to this new approach, the child, as field of study, is not homogeneous; it has locally/culturally different childhood conceptions and the main task of sociology of childhood should be to observe these differences in the production process of scientific knowledge. Scientists who adopted the interpretive approach in the new childhood sociology used the concept of interpretive production as an alternative to the concept of socialization. Traditional childhood understanding was shaped mostly under the influence of the positivist approach and focused on quantitative research method. The new childhood sociology, on the other hand, has predominantly focused on qualitative research methods as well as the quantitative method.

Formed in sociology after the 1980s, the foundations of the new sociology of childhood are based on childhood studies that have been flourished in the USA for 19201930s. The important feature of this classical approach which was called traditional sociology of childhood, is that it has been influenced by childhood studies produced in other 
disciplines for a long time. Developmental psychology, a sub-branch of psychology in particular, maintained its hegemony not only in sociology, but also in childhood studies which was produced in other social sciences other than psychology. It can be said that, the concepts of "universality, naturalness and rationality" shaped the studies of childhood sociology in the first period with the effect of this restriction.

Regarding the historical development worldwide, it is seen that the pioneering studies of sociology of childhood are predominantly carried out in the USA, England and Germany. In sociology of childhood, the USA and the UK pioneered experimental research, while Germany was a guide in theoretical studies. The theoretical foundations of the new sociology of childhood were laid in England, especially in the 1990s, when Alan Prout and Allison James criticized the passive socialization-focused approach to children and suggested a different understanding of childhood.

It can be said that the two developments that emerged at the end of the 1960s were efficacious in the advancement of the new sociology of childhood. One of these developments, the feminist movement, has succeeded in guiding comprehensive and indepth childhood studies with its academic productivity. The feminist movement first burgeoned out in the USA in the 1960s and became widespread in Europe in the 1970s. The feminist movement has, from a critical perspective, questioned the roles and responsibilities of childcare in the context of the gender roles available in the family, by referring to their unequal positions and contributing to the handling of children in terms of social problems such as sexual abuse, domestic violence, poverty and rights. Another development that maturates the new sociology of childhood has come along children rights. The debate on the Convention on the Children Rights, which is the first international contract adopted by the United Nations General Assembly on 20 November 1989, has reinforced the sociological view that children, together with the approach of public policies toward child abuse and protection, should be treated as social actors.

The sociology of childhood in Turkey, comparing with US and European countries, made advancement at relatively later date. Childhood studies are first encountered in the Ottoman period. In the last years of the Ottoman Empire, it is seen that the issue of children was covered in the context of westernization, family and reforms on education. During the founding years of the Republic, children were mainly tackled in the context of family, state and religious institutions. In spite of the fact that there is a comprehensive literature on the childhood studies in Turkey, we cannot speak yet of the existence of a rich literature. It is observed that studies contributing to the sociology of childhood have accelerated particularly in recent years. These studies, which examine the child in a sociological dimension, discuss the theories created for children and -with the guidance of these theorieskeep the interest on the social problems faced by the child.

In general, the topic selection and handling style of sociology of childhood has followed the course of development parallel to social and scientific developments. Industrialization, capitalism and the development of the concept of children's rights, the effects of globalization and ideology, political and economic developments, the development of social policies, legal developments, the development of welfare policies and developments in the media industry have, all in the historical process, been effective in bringing up children problems and children rights into the agenda. The emphasis of the new sociology of childhood on different childhood forms and on the social agency of the child 
has revealed the need of discussion within the scope of issues such as globalization, media, children's rights, social exclusion, privacy, violence, culture, inequality, policy, civil society, gender, health, intergenerational difference and environment. Undoubtedly, studies to be conducted in the field of new sociology of childhood will also increase the interest and need to address children as part of sociological issues.

Makale Bilgileri

Etik Kurul Kararı:

Etik Kurul Kararından muaftır.

Katılımcı Rızası:

Katılımc1 yoktur

Mali Destek:

Çalışma için herhangi bir kurum ve projeden mali destek alınmamıştır.

Çıkar Çatışması:

Çalışmada kişiler ve kurumlar arası çıkar çatışması bulunmamaktadır.

Telif Hakları:

Telif hakkına sebep olacak bir materyal kullanılmamıştır.

Article Information

Ethics Committee Approval: Exempt from the Ethics Committee Decision.

Informed Consent:

No participants

Financial Support:

No financial support from any institution or project.

Conflict of Interest:

No conflict of interest.

Copyrights:

No material subject to copyright is included. 


\section{KAYNAKÇA}

Agamben, G. (2010). Çocukluk ve tarih-Deneyimin yıkımı üzerine bir deneme (B. Parlak, Çev.). İstanbul: Kanat Kitap.

Akın, M. H. (2015). Toplumsallaşma sözlüğüu. Konya: Çizgi Kitabevi.

Andresen, S., Fegter, S., Hurrelmann, K., Pupeter, M. ve Schneekloth, U. (2015). Child poverty in Germany: Conceptual aspects and core findings. E. Fernandez, A. Zeira, T. Vecchiato ve C. Canali (Ed.), Theoretical and empirical insights into child and family poverty: Cross national perspectives içinde (s. 127-140). Children's Well-Being: Indicators and Research Series 10. Switzerland: Springer International Publishing.

Ariés, P. (1962). Centuries of childhood-A social history of family life (R. Baldick, Trans.). New York: Jonathan Cape Press.

Axford, N. (2008). Exploring concepts of child well-being: implications for children's services. Great Britain: The Policy Press.

Baraldi, C. (2010). Children's citizenships: Limitations and possibilities of childhood sociology in Italy. Current sociology, 58(2), 272-291.

Bass, L.E. (2010). Childhood in sociology and society the US perspective. Current Sociology, 58(2), 335-350.

Bradbury, B., Jenkins, S. P. ve Micklewright, J. (Ed.). (2001). The dynamics of child poverty in industrialised countries. United Kingdom: Cambridge Unıversity Press.

Canatan, K. (2013). Dünya'da ve Türkiye' de çocuk algıları ve cinsiyet öncelikleri. K. Canatan ve E. Yıldırım (Ed.), Aile sosyolojisi içinde (s.197-213). İstanbul: Açılım Kitap.

Canatan, K. ve Yıldırım, E. (ed). (2013). Aile Sosyolojisi. İstanbul: Açılım Kitap.

Cockburn, T. (2010). Children, the feminist ethic of care and childhood studies: Is this the way to the good life?. S. Andresen, I. Diehm, U. Sander ve H. Ziegler (Ed.), Children and the good life: New challenges for research on children içinde (s. 29-39). Netherlands: Springer.

Corsaro, W. A. (2005). The sociology of childhood. UK: Pine Forge Press.

Çöpoğlu, M. (2018). Türkiye'de çocuk işçiliği. Iğdır Üniversitesi Sosyal Bilimler Dergisi, 14, 357398.

Daniel, P. ve Ivatts, J. (1998). Children and social policy. New York: Palgrave Publish.

Doğan, İ. (2000). Akıllı küçük-Çocuk Kültürü ve çocuk hakları üzerine sosyo-kültürel bir inceleme. İstanbul: Sistem Yayıncılık.

Doğan, İ. (2016). Türk aile sosyolojisi. Ankara: Pegem Akademi.

Eğribel, E. (2019). Çocukluk sosyolojisi için evrensel giriş. Çocuk ve Medeniyet Dergisi, 4(7), 4159.

Ellis, J. M. (2010). Reflections on the sociology of childhood in the UK. Current Sociology, 58(2), 186-205.

Eraslan, L. (2015). Çocukluk sosyolojisine giriş. L. Eraslan (Ed.), Farklı perspektiflerden çocukluk ve sosyolojisi içinde (s.14-37). Ankara: Vize Yayıncllık.

Eraslan, L. (Ed.). (2015). Farklı perspektiflerden çocukluk ve sosyolojisi. Ankara: Vize Yayıncılık.

Ercan, R. (2011). Modern çocukluk paradigması. Journal of World of Turks, 3(2), 85-98. 
Fernandez, E., Zeira, A., Vecchiato, T. ve Canali, C. (Ed.). (2015). Theoretical and empirical insights into child and family poverty: Cross national perspectives. Children's Well-Being: Indicators and Research Series 10. Switzerland: Springer International Publishing.

Franklin, B. (1993). Çocuk hakları (A. Türker, Çev.). İstanbul: Ayrıntı Yayınları.

Friedman, S. ve Lichter, D.T. (1998). Spatial inequality and poverty among American children. Population Research and Policy Review, 17, 91-109.

Giddens, A. (2008). Sosyoloji (C. Güzel, Haz.). İstanbul: Kırmızı Yayınları.

Gottschalk, P. ve Danziger, S. (2001). Income mobility and exits from poverty of American children. B. Bradbury, S. P Jenkins ve J. Micklewright (Ed.), The dynamics of child poverty in industrialised countries içinde (s. 135-153), United Kingdom: Cambridge University Press.

Güçlü, S. (2016). Çocukluk ve çocukluğun sosyolojisi bağlamında çocuk hakları. Sosyoloji Dergisi, (1), 1-22.

Güllü, İ. (2015). Yeni çocuk sosyolojisi bağlamında Almanya'daki göçmen Türk çocuklarının dini toplumsallaşması. Sosyoloji Divanı, 6, 83-102.

Gürdal, A. D. (2013). Sosyolojinin ihmal edilen kategorisi çocuklar üzerinden çocukluk sosyolojisine ve sosyolojiye bakmak. "İş, Güç", Endüstri İlişkileri ve İnsan Kaynakları Dergisi, 15(4), 1-26.

Gürsoy, A. (2010). Childhood studies in Turkey. S. Andresen, I. Diehm, U. Sander ve H. Ziegler (Ed.), Children and the good life içinde (s.141-157). Netherlands: Springer.

Hammersley, M. (2019). Çocukluk çalışmaları: sürdürülebilir bir paradigma mı?. (E. Akbaş, Çev.). Çocuk ve Medeniyet Dergisi, 4(7), 61-79.

Hill, M. S. ve Jenkins, S. P. (2001). Poverty among British children: Chronic or transitory?. B.Bradbury, S. P Jenkins ve J. Micklewright (Ed.), The dynamics of child poverty in industrialised countries içinde (s. 174-195), United Kingdom: Cambridge University Press.

Holt, J. (2000). Çocukluktan kaçış (S. Yılancı ve C. Aksoy, Çev.). İstanbul: Beyaz Yayınları.

İnal, K. (1999). Paternalist politikanın ideal Türk çocuğu. Ankara Üniversitesi Ĕ̆itim Bilimleri Fakültesi Dergisi, 32(1), 195-212.

İnal, K. (2007a). Çocuğun örselenen dünyası. Ankara: Sobil Yayıncılık.

İnal, K. (2007b). Modernizm ve çocuk-Geleneksel, modern ve postmodern çocukluk İmgeleri. Ankara: Sobil Yayıncilik.

James, A. (2001). 'Yeni' çocukluk sosyolojisinde sorunlar, yaklaşımlar ve pratikler. B. Onur (Haz.), Dünyada ve Türkiye'de değişen çocukluk-3.Ulusal çocuk kültürü kongresi bildirileri içinde (s. 27-36). Ankara: Ankara Üniversitesi Çocuk Kültürü Araştırma ve Uygulama Merkezi Yayınları.

James, A. ve James. A. (2004). Constructing childhood-theory, policy and social practice. New York: Palgrave Macmillan.

James, A. ve James. A. (2004). Introduction. A. James ve A. Prout (Ed.), Constructing childhood- theory, policy and social practice içinde (s.1-6). New York: Palgrave Macmillan.

Jenks, C. (2002). Childhood. New York: Routledge Press.

SEFAD, 2020; (44): 461-486 
Johnson, H. B. (2001). From the Chicago school to the new sociology of children- The sociology of children and childhood in the United States, 1900-1999. Advances in Life Course Research, 6, 53-93.

Kaçmazoğlu, H. B. (2013). Mehmet Ali Şevki Sevündük ve İsmayıl Hakkı Baltacığlu. M. Ç. Özdemir (Ed.), Türk Sosyologları içinde (s.44-65). Eskişehir: Anadolu Üniversitesi Yayınları.

Kadir, C. ve Yıldırım, E. (Ed.). (2013). Aile sosyolojisi. İstanbul: Açılım Kitap.

Karaduman, E. ve Gökgöz, E. (2017). TRT yerli çocuk programlarında çocukluğun inşası: Eğitim, toplumsallaşma, politik özne biçimleri. TRT Akademi Dergisi, 2(4), 377-397.

Kaya, N.Ç. (2012). Aile ve çocuk. A. Kasapoğlu ve N. Karkıner (Ed.), Aile sosyolojisi içinde (s.106-133). Eskişehir: Anadolu Üniversitesi Yayınları.

Kimberlin, S. ve Berrick, J. D. (2015). Poor for how long? Chronic versus transient child poverty in the United States. E. Fernandez, A. Zeira, T. Vecchiato ve C. Canali (Ed.),c Theoretical and empirical insights into child and family poverty: Cross national perspectives içinde (s. 141-158), Children's Well-Being: Indicators and Research Series 10. Switzerland: Springer International Publishing.

Kitzinger, J. (2005). Who are you kidding? Children, power and the struggle against sexual abuse'. A. James ve A. Prout (Ed.), Constructing and reconstructing childhood içinde (s.161186). London: Falmer Press.

Krieken, R. V. (2010). Childhood in Australian sociology and society. Current Sociology, 58(2), 232-249.

Leonard, M. (2019). Çocuklar, çocukluk ve sosyal sermaye: bağlantıların incelenmesi. Çocuk ve Medeniyet Dergisi, 4(7), 105-124.

Lindsey, D. (2009). Child poverty and inequality: Securing a better future for America's children. New York: Oxford University Press.

Matthews, S. H. (2007). A window on the 'new' sociology of childhood. Sociology Compass, $1(1), 322-334$.

Mayall, B. (2001). The sociology of childhood in relation to children's rights. The International Journal of Children's Rights, 8, 243-259.

Mayall, B. (2018). Çocukluk sosyolojisi tarihi (T. F. Orman, Çev.). İstanbul: Beta Basım Yayın.

Mayall, B. (Ed.). (2003). Children's childhoods: Observed and experienced. London: The Falmer Press.

Morrow. V. (2003). Responsible children? Aspects of children's Work and employment outside school in contemporary UK. B. Mayall (Ed.), Children's childhoods: observed and experienced içinde (128-143). London: The Falmer Press.

Mullender, A., Hauge. G., Imam, U., Kelly, L., Malos, E. ve Regan, L. (2002). Children's perspectives on domestic violence. London: Sage Publications.

Niederberger, D. B. (2010). Childhood sociology in ten countries- Current outcomes and future directions. Current Sociology, 58(2), 369-384.

Oakley, A. (2003). Women and children first and last: Parallels and differences between children's and women's studies. B. Mayall (Ed.), Children's childhoods: Observed and experienced içinde (13-32). London: The Falmer Press.

Onur, B. (1994). Toplumsal tarihte çocuk. İstanbul: Tarih Vakfı Yurt Yayınları. 
Onur, B. (2005). Türkiye'de Çocukluğun Tarihi. Ankara: İmge Kitabevi.

Onur, B. (2007). Çocuk, tarih ve toplum. Ankara: İmge Kitabevi.

Onur, B. (2019). Değişen çă̆ değgişen çocuk. Ankara: İmge Kitabevi.

Özarslan, A. D. (2016). Çocuk ve çocukluk sosyolojisi. İstanbul: Resse Kitabevi.

Özyurt, C. (2017). Çocukluk sosyolojisi: Bir giriş denemesi. Eğitim sosyolojisi yazıları içinde (s. 126-163). Ankara: Pegem Akademi.

Özyurt, C. (2017). Eğitim sosyolojisi yazıları. Ankara: Pegem Akademi.

Pembecioğlu, N. (1997). Çocukluklarını yitiren çocuklar üstüne. İstanbul Üniversitesi İletişim Fakültesi Dergisi, 6, 253-277.

Pilcher, J. ve Wagg, S. (1996). Thatcher's children? Politics, childhood and society in the 1980s and 1990s. London: Palmer Press.

Postman, N. (1995). Çocukluğun yokoluşu (K. İnal, Çev.). Ankara: İmge Kitabevi.

Prout, A. ve James, A. (2005). A new paradigm for the sociology of childhood? Provenance, promise and problems. A. James ve A. Prout (Ed.), Constructing and reconstructing childhood-Contemporary issues in the sociological study of childhood içinde (s. 7-32). London: Falmer Press.

Prout, A. ve James, A. (Ed.). (2005). Introduction. A. James ve A. Prout (Ed.), Constructing and reconstructing childhood-Contemporary issues in the sociological study of childhood içinde (s. 1-6). London: Falmer Press.

Qvortrup, J. (2005) . A Voice for children in statistical and social accounting: A plea for children's right to be heard. A. James. ve A. Prout (Ed.), Constructing and reconstructing childhood- Contemporary issues in the sociological study of childhood içinde (s.83-103). London: Falmer Press.

Qvortrup, J., Corsaro, W.A. ve Honig, M.S. (Ed.). (2009). The palgrave handbook of childhood studies. New York: Palgrave Macmillan.

Ridge, T. (2002). Childhood poverty and social exclusion: From a child's perspective. Great Britain: The Policy Press.

Schluter, C. (2001). Child poverty in Germany: Trends and persistence. B.Bradbury, S. P Jenkins ve J. Micklewright (Ed.). The dynamics of child poverty in industrialised countries içinde(s. 154-173), United Kingdom: Cambridge University Press.

Sirota, R. (2010). French childhood sociology: An unusual, minor topic or well-defined field?. Current Sociology, 58(2), 250-271.

Stearns, P. N. (2018). Çocukluğun tarihi (H. Dikmen ve B. Uçar, Çev.). İstanbul: Dedalus Kitap.

Strandell, H. (2010). From structure-action to politics of childhood-Sociological childhood research in Finland. Current Sociology, 58, (2), 165-185.

Şirin, M. R. (2017). Önsöz, Kuşatılmış çocukluğun öyküsü içinde (s.9-11). İstanbul: İz Yayıncılık.

Şirin, M. R. (2019). Değişen çocuk ve çocukluk (Biraz tarih ve felsefe biraz sosyoloji ve çocukluk sosyolojisi). Çocuk ve Medeniyet Dergisi, 4(7), 5-39.

Tan, M. (1989). Çağlar boyunca çocukluk. Ankara Üniversitesi Eğitim Bilimleri Fakültesi Dergisi, 22(1), 71-88.

Tezcan, M. (1985). Eğitim sosyolojisi. Ankara: Ankara Üniversitesi Eğitim Bilimleri Fakültesi Yayınları. 
Tezcan, M. (2017). Çocukluk sosyolojisi. Ankara: Anı Yayıncılık.

Turmel, A. (2008). A historical sociology of childhood. New York: Cambridge University Press.

Yavuzer, H. (2019). Çocuk ve Suç. İstanbul: Remzi Kitabevi.

Yeakey, C.C., J.W. Richardson ve J.B. Buck (Ed.). (2006). 'Suffer the little children': National and international dimensions of child poverty and public policy. Advances in Education in Diverse Communities: Research, Policy and Praxis, 4, Oxford: Elsevier Ltd.

Yelken, R. (2013). Çocuk suçluluğunu önlemenin temeli olarak uluslararası çocuk sözleşmeleri ve aileye verilen önem. K. Canatan ve E. Yıldırım (Ed.), Aile sosyolojisi içinde (s.183-195). İstanbul: AçllımKitap.

Zabun, B. (2019). Türkiye'de eğitim sosyolojisinin gelişimi. Ç. Özdemir ve A. S. Arslangilay (Ed.), Ĕ̆itim sosyolojisi içinde (s.116-141), Ankara: Pegem Akademi.

Zeiher, H. (2010). Childhood in German sociology and society. Current Sociology, 58(2), 292308. 